\title{
REVIEW
}

\section{Physiology of the pancreatic $\alpha$-cell and glucagon secretion: role in glucose homeostasis and diabetes}

\author{
Ivan Quesada, Eva Tudurí, Cristina Ripoll and Ángel Nadal \\ CIBER de Diabetes y Enfermedades Metabólicas Asociadas (CIBERDEM) and Instituto de Bioingeniería, Universidad Miguel Hernández, Avenida de la \\ Universidad s/n, 03202 Elche, Spain \\ (Correspondence should be addressed to I Quesada; Email: ivanq@umh.es)
}

\begin{abstract}
The secretion of glucagon by pancreatic $\boldsymbol{\alpha}$-cells plays a critical role in the regulation of glycaemia. This hormone counteracts hypoglycaemia and opposes insulin actions by stimulating hepatic glucose synthesis and mobilization, thereby increasing blood glucose concentrations. During the last decade, knowledge of $\boldsymbol{\alpha}$-cell physiology has greatly improved, especially concerning molecular and cellular mechanisms. In this review, we have addressed recent findings on $\alpha$-cell physiology and the regulation of ion channels, electrical activity, calcium signals and glucagon release. Our focus in this review has been the multiple control levels that modulate
\end{abstract}

glucagon secretion from glucose and nutrients to paracrine and neural inputs. Additionally, we have described the glucagon actions on glycaemia and energy metabolism, and discussed their involvement in the pathophysiology of diabetes. Finally, some of the present approaches for diabetes therapy related to $\alpha$-cell function are also discussed in this review. A better understanding of the $\boldsymbol{\alpha}$-cell physiology is necessary for an integral comprehension of the regulation of glucose homeostasis and the development of diabetes.

Journal of Endocrinology (2008) 199, 5-19

\section{Introduction}

The principal level of control on glycaemia by the islet of Langerhans depends largely on the coordinated secretion of glucagon and insulin by $\alpha$ - and $\beta$-cells respectively. Both cell types respond oppositely to changes in blood glucose concentration: while hypoglycaemic conditions induce $\alpha$-cell secretion, $\beta$-cells release insulin when glucose levels increase (Nadal et al. 1999, Quesada et al. 2006a). Insulin and glucagon have opposite effects on glycaemia as well as on the metabolism of nutrients. Insulin acts mainly on muscle, liver and adipose tissue with an anabolic effect, inducing the incorporation of glucose into these tissues and its accumulation as glycogen and fat. By contrast, glucagon induces a catabolic effect, mainly by activating liver glycogenolysis and gluconeogenesis, which results in the release of glucose to the bloodstream. An abnormal function of these cells can generate failures in the control of glycaemia, which can lead to the development of diabetes (Dunning et al. 2005). Actually, diabetes is associated with disorders in the normal levels of both insulin and glucagon. An excess of glucagon plasma levels relative to those of insulin can be determinant in the higher rate of hepatic glucose output, which seems to be critical in maintaining hyperglycaemia in diabetic patients (Dunning et al. 2005).

Despite the importance of the $\boldsymbol{\alpha}$-cell and glucagon secretion in the regulation of glycaemia and nutrient homeostasis, little is known about the physiology of these cells compared with the overwhelming information about $\beta$-cells. Several factors may explain this lack of information about glucagon secretion. First, the scarcity of this cell population in islets of animal models such as mice and rats along with several technical limitations of conventional methods have made it more difficult to study $\alpha$-cells than $\beta$-cells (Quoix et al. 2007). Second, the lack of functional identification patterns has also been an important limitation in $\alpha$-cell research. However, in recent years notable progress has been made in the study of $\boldsymbol{\alpha}$-cell function at the cellular and molecular levels. This review attempts to describe recent advances in $\alpha$-cell physiology and the regulation of glucagon secretion. Additionally, it focuses on the pathophysiology of these cells, their role in diabetes, as well as potential therapeutic strategies. 


\section{Islet of Langerhans: cell architecture and function}

Glucagon-secreting $\alpha$-cells are one of the main endocrine cell populations that coexist in the islet of Langerhans along with insulin-secreting $\beta$-cells. The islet is further composed by other scarce secretory populations such as $\delta$ - and polypeptide releasing (PP)-cells, which release somatostatin and pancreatic polypeptide respectively. This multicellular structure constitutes the endocrine unit of the pancreas and is responsible for the regulation of blood glucose homeostasis. Approximately one million islets are distributed throughout a healthy adult human pancreas, representing 1 and $2 \%$ of the total mass of the organ. Each islet, with sizes varying from 100 to $500 \mu \mathrm{m}$, is made up of $1000-3000$ cells. In mouse and rat islets, $\beta$-cells are the main population accounting for $60-80 \%$ of the total number of cells, while $15-20 \%$ are $\alpha$-cells, $<10 \%$ are $\delta$-cells and less than $1 \%$ correspond to the PP-cell population (Brelje et al. 1989, Brissova et al. 2005). The architecture of rodent islets is characterized by the location of $\beta$-cells in the core and the non- $\beta$ cells distributed in a mantle around the insulin-secreting cell population. This cellular distribution along with several studies on microcirculation within the islet suggests that the order of paracrine interactions is from $\beta$ - to $\alpha$ - and $\delta$-cells (Bonner-Weir 1991). The rich vascularization within the islet ensures a rapid sensing of plasma glucose levels by these endocrine cells, allowing an appropriate secretory response. In human islets, however, there are important differences in composition and spatial organization compared with rodents (Cabrera et al. 2006). While the proportion of $\delta$ - and $\mathrm{PP}$-cells are similar in the human islet, $\beta$-cells are less abundant $(48-59 \%)$ and the $\alpha$-cell population reaches a $33-46 \%$, suggesting that glucagon secretion plays a major role in humans (Cabrera et al. 2006). These islet cell populations show a random distribution pattern, where the majority of $\beta$-cells are in contact with non- $\beta$-cells, suggesting that paracrine interactions among different populations may be more active (Cabrera et al. 2006). Another divergence between human and rodent islets is the intercellular communication among the different populations. In mice, $\beta$-cells work as a syncytium in terms of electrical activity and $\mathrm{Ca}^{2+}$ signalling due to the high level of coupling mediated by gap junctions of connexin36 (Gopel et al. 1999, Nadal et al. 1999, Quesada et al. 2003). This coupling favours a more vigorous insulin secretion (Vozzi et al. 1995). By contrast, coupling can be found between several human $\beta$-cells in clusters within the same islet but not in the whole $\beta$-cell population (Quesada et al. 2006b). This kind of intercellular communication is probably the result of the human islet cytoarchitecture and its functional meaning is still unknown (Cabrera et al. 2006). Unlike $\beta$-cells, $\alpha$ - and $\delta$-cells from rodents and humans are not functionally coupled and work as independent units. In addition to nutrients and paracrine signals, islet function is further regulated by sympathetic, parasympathetic and sensory nerves that go deeply into the islet (Ahren 2000). Thus, multiple regulation levels determine hormone release from pancreatic islets.

\section{Glucagon secretion by pancreatic $\alpha$-cells}

Stimulus-secretion coupling in $\alpha$-cells: from ion channel activity to exocytosis

Pancreatic $\alpha$-cells are equipped with a specific set of channels that generate action potentials of $\mathrm{Na}^{+}$and $\mathrm{Ca}^{2+}$ in the absence or at low levels of glucose (Gromada et al. 1997). This electrical activity triggers $\mathrm{Ca}^{2+}$ signals and glucagon secretion. Elevated glucose concentrations inhibit all these events. ATP-dependent $\mathrm{K}^{+}\left(\mathrm{K}_{\text {ATP }}\right)$ channels play a fundamental role in $\alpha$-cells, such as they do in $\beta$-cells, since they couple variations in extracellular glucose concentrations to changes in membrane potential and electrical activity. In intact rat $\alpha$-cells, $\mathrm{K}_{\text {ATP }}$ channels have a lower ATP sensitivity $\left(K_{\mathrm{i}}=0.94 \mathrm{mM}\right)$ than the one observed in excised patches ( $K_{\mathrm{i}}=16 \mu \mathrm{M}$; Bokvist et al. 1999, Gromada et al. 2007), but a very similar one to the values recorded in mouse and rat intact $\beta$-cells. However, $\mathrm{K}_{\mathrm{ATP}}$ channels exhibit a higher ATP sensitivity in intact mouse $\alpha$-cells $\left(K_{\mathrm{i}}=0.16 \mathrm{mM}\right.$; Leung et al. 2005). Consequently, lower ATP concentrations are required to obtain the maximal inhibition of $\mathrm{K}_{\mathrm{ATP}}$ conductance compared with mouse $\beta$-cells. Recent evidence has indicated that the densities of these channels are similar in mouse $\alpha$ - and $\beta$-cells (Leung et al. 2005). The repolarization of action potentials is mediated by voltage-dependent $\mathrm{K}^{+}$channels. While delayed rectifying $\mathrm{K}^{+}$channels have been demonstrated in rat, mouse and guinea pig $\alpha$-cells, a tetraethylammonium-resistant voltage-dependent $\mathrm{K}^{+}$current (A-current) has only been identified in mice (Barg et al. 2000, Leung et al. 2005). Furthermore, tetrodotoxin-sensitive $\mathrm{Na}^{+}$currents are fundamental for the generation of action potentials in these cells. $\mathrm{Na}^{+}$channels are activated at voltages above -30 to $-20 \mathrm{mV}$ (Gopel et al. 2000), and their blockade by tetradotoxin leads to the inhibition of glucagon secretion (Gromada et al. 2004, Olsen et al. 2005, MacDonald et al. 2007). Additionally, $\alpha$-cells have a heterogeneous presence of $\mathrm{Ca}^{2+}$ channel subtypes with different roles. While $\mathrm{L}$ and $\mathrm{N}$ channels have been reported in rat $\boldsymbol{\alpha}$-cells (Gromada et al. 1997), mouse $\alpha$-cells express L-, T-, N- and probably R-type $\mathrm{Ca}^{2+}$ channels (Gopel et al. 2000, Gromada et al. 2004, Pereverzev et al. 2005, MacDonald et al. 2007). The low voltage-activated T-type channels work as pacemakers in the initiation of action potentials in mice (Gopel et al. 2000). They open around $-60 \mathrm{mV}$, the action potential initiation threshold in $\alpha$-cells. The high voltage-activated $\mathrm{L}$ and $\mathrm{N}$ channels open during action potentials when the membrane potential exceeds -40 to $-30 \mathrm{mV}$. Although most of the $\mathrm{Ca}^{2+}$ current goes through L-type channels in $\alpha$-cells, the $\mathrm{Ca}^{2+}$ required for exocytosis at low-glucose levels is mediated by N-type channels, and their blockade by $\omega$-conotoxin-GVIA inhibits glucagon secretion in these 
conditions (Gromada et al. 1997, 2004, Olsen et al. 2005, MacDonald et al. 2007). However, in the presence of cAMPelevating agents, $\mathrm{L}$ channels are the major conduit for $\mathrm{Ca}^{2+}$ (Gromada et al. 1997).

A model to explain the glucose regulation of electrical activity in mouse $\alpha$-cells has been postulated in the light of recent studies (Fig. 1). At low-glucose levels, the activity of $\mathrm{K}_{\text {ATP }}$ channels renders a membrane potential of about $-60 \mathrm{mV}$. At this voltage, T-type channels open, which depolarize the membrane potential to levels where $\mathrm{Na}^{+}$and $\mathrm{N}$-type $\mathrm{Ca}^{2+}$ channels are activated, leading to regenerative action potentials (Gromada et al. 2004, MacDonald et al. 2007). $\mathrm{Ca}^{2+}$ entry through N-type channels induces glucagon secretion. The repolarization of action potentials is mediated by the flowing of $\mathrm{K}^{+} \mathrm{A}$-currents. At low-glucose concentrations, this electrical activity triggers oscillatory $\mathrm{Ca}^{2+}$ signals in both human and mouse $\alpha$-cells in intact islets (Nadal et al. 1999, Quesada et al. 1999, 2006b; Fig. 2).

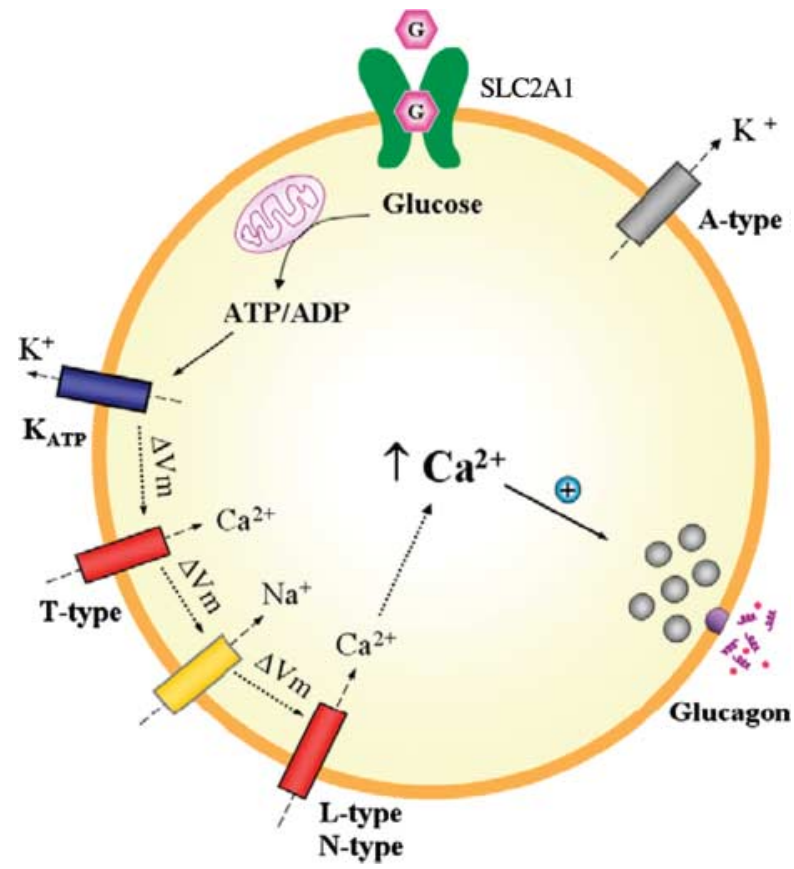

Figure 1 Schematic model for glucose-dependent regulation of glucagon secretion in the mouse $\alpha$-cell. Glucose is incorporated into the $\alpha$-cell by the transporter SLC2A1. At low-glucose concentrations, the moderate activity of $\mathrm{K}_{\text {ATP }}$ channels situates the $\alpha$-cell membrane potential in a range that allows the opening of voltage-dependent $\mathrm{T}$ - and $\mathrm{N}$-type $\mathrm{Ca}^{2+}$ channels and voltagedependent $\mathrm{Na}^{+}$channels. Their activation triggers action potentials, $\mathrm{Ca}^{2+}$ influx and exocytosis of glucagon granules. The opening of A-type $\mathrm{K}^{+}$channels is necessary for action potential repolarization. However, high-glucose concentrations elevate the intracellular ATP/ADP ratio, blocking $\mathrm{K}_{\text {ATP }}$ channels and depolarizing the membrane potential to a range where the inactivation of voltage-dependent channels takes place. This results in the inhibition of electrical activity, $\mathrm{Ca}^{2+}$ influx and glucagon secretion. The function of L-type channels predominates when cAMP levels are elevated. See text for further details.

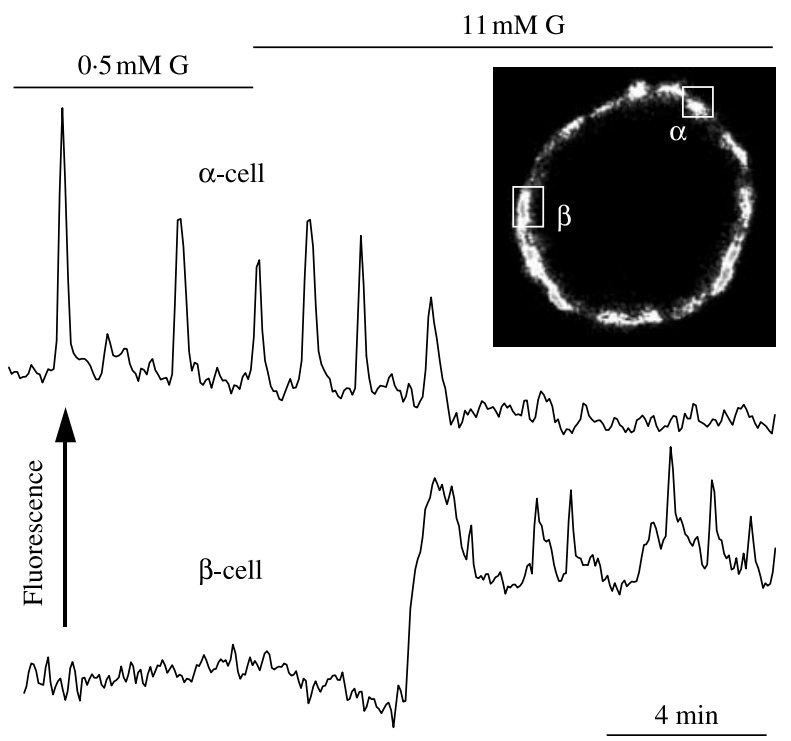

Figure 2 Opposite $\mathrm{Ca}^{2+}$ signalling patterns in $\alpha$ - and $\beta$-cells in response to glucose. At low-glucose concentrations $(0.5 \mathrm{mM})$, electrical activity triggers oscillatory $\mathrm{Ca}^{2+}$ signals in $\alpha$-cells that lead to glucagon release. Elevation of glucose levels (11 mM) inhibits all these events. By contrast, $11 \mathrm{mM}$ glucose stimulate $\mathrm{Ca}^{2+}$ signalling and insulin secretion in $\beta$-cells. Both fluorescence records were obtained by confocal microscopy from two cells within an intact mouse islet. Inset shows a thin optical section $(\sim 6 \mu \mathrm{m})$ of a mouse islet loaded with the $\mathrm{Ca}^{2+}$-sensitive fluorescent probe Fluo-3.

However, the increase in extracellular glucose levels rises the cytosolic ATP/ADP ratio which blocks $\mathrm{K}_{\mathrm{ATP}}$ channels, depolarizing $\boldsymbol{\alpha}$-cells to a membrane potential range where the channels involved in action potentials become inactivated (Gromada et al. 2004, MacDonald et al. 2007). As a consequence, electrical activity, $\mathrm{Ca}^{2+}$ signals and glucagon secretion are inhibited (Figs 1 and 2). Thus, glucagon release from $\alpha$-cells is mainly supported by an intermediate $\mathrm{K}_{\mathrm{ATP}}$ channel activity that maintains a membrane potential range able to sustain regenerative electrical activity (MacDonald et al. 2007). A similar model has been also proposed for human $\alpha$-cells (MacDonald et al. 2007). Nevertheless, this scheme has been argued by some reports indicating that glucose may be hyperpolarizing rather than depolarizing (Liu et al. 2004, Manning Fox et al. 2006). It has also been proposed that glucose would inhibit glucagon secretion by suppressing a depolarizing $\mathrm{Ca}^{2+}$ store-operated current independent of $\mathrm{K}_{\text {ATP }}$ channels (Liu et al. 2004, Vieira et al. 2007).

In rat $\alpha$-cells, the activity of $\mathrm{K}_{\mathrm{ATP}}$ channels at low-glucose concentrations also keeps the membrane potential at about $-60 \mathrm{mV}$, where spontaneous $\mathrm{Na}^{+}$and $\mathrm{Ca}^{2+}$ action potentials are produced (Gromada et al. 1997). However, in contrast to the situation in mice, the stimulus-secretion coupling in rat $\alpha$-cells is similar to that of $\beta$-cells. That is, elevations of extracellular glucose levels increase the intracellular ATP/ADP ratio, blocking $\mathrm{K}_{\mathrm{ATP}}$ channels and depolarizing the membrane potential, which stimulates $\mathrm{Ca}^{2+}$ 
influx through $\mathrm{N}$ channels and glucagon secretion (Franklin et al. 2005, Olsen et al. 2005). Accordingly, the pharmacological inhibition of glucose metabolism increases $\mathrm{K}_{\mathrm{ATP}}$ channel activity in rat $\alpha$-cells (Olsen et al. 2005). This model indicating a $\beta$-cell-like stimulus-secretion coupling is based on recent studies that have used isolated rat $\alpha$-cells. However, these results contrast with the observations showing that glucose inhibits $\boldsymbol{\alpha}$-cell electrical activity and glucagon secretion in intact rat islets (Franklin et al. 2005, Manning Fox et al. 2006). Therefore, the blocking effect observed in rat islets at high-glucose concentrations is most likely the result of paracrine signalling by $\beta$-cell activation (Wendt et al. 2004).

\section{Regulation of $\alpha$-cell function by glucose: direct or paracrine effect?}

Whether glucose inhibits $\alpha$-cells directly or by paracrine mechanisms has been a matter of debate, and, probably, the predominant level of control may depend on the physiological situation. Part of this controversy is also due to the divergences found in the stimulus-secretion coupling of different animal models. Although paracrine signalling may be critical for the glucose inhibition of glucagon secretion in rats (Wendt et al. 2004, Franklin et al. 2005, Olsen et al. 2005), a direct effect has been observed in mice and humans (Asplin et al. 1983, MacDonald et al. 2007). In mice and humans, a glucose direct action on $\alpha$-cells has been proven in isolated cells under conditions where paracrine effects are negligible, and in intact islets incubated with different paracrine signalling inhibitors (Gromada et al. 2004, Ravier \& Rutter 2005, Shiota et al. 2005, MacDonald et al. 2007, Vieira et al. 2007). Moreover, secretion studies prove that glucose inhibits glucagon release at concentrations below the threshold for $\beta$-cell activation and insulin release (MacDonald et al. 2007, Vieira et al. 2007).

Several reports on experiments using genetic mouse models support the role of glucose-modulated $\mathrm{K}_{\mathrm{ATP}}$ channels in $\boldsymbol{\alpha}$-cell function. The regulation of glucagon secretion by glucose is impaired in ABCC8-deficient mice lacking functional $\mathrm{K}_{\mathrm{ATP}}$ channels (Gromada et al. 2004, Munoz et al. 2005). A similar situation occurs in KCNJ11Y12X mouse with a KCNJ11 mutation in the $\mathrm{K}_{\text {ATP }}$ channel (MacDonald et al. 2007). In humans, the Glu23Lys polymorphism in the KCNJ11 subunit of these channels is associated with diminished suppression of glucagon release in response to hyperglycaemia (Tschritter et al. 2002). Nevertheless, since $K_{\text {ATP }}$ channels seem to be essential for the $\alpha$-cell regulation in the proposed models, some considerations on glucose metabolism should be taken into account. Although $\boldsymbol{\alpha}$-cells possess the high-affinity, lowcapacity glucose transporter SLC2A1, instead of the highcapacity SLC2A2 present in the $\beta$-cell, it has been demonstrated that glucose transport is not a limiting factor in $\boldsymbol{\alpha}$-cell glucose metabolism (Gorus et al. 1984, Heimberg et al. 1995, 1996). However, several studies indicate that important biochemical differences exist between both cell types. While the ratio of lactate dehydrogenase/mitochondrial glycerol phosphate dehydrogenase is low in the $\beta$-cell, this ratio is higher in non- $\beta$ cells (Sekine et al. 1994). Additionally, $\alpha$-cells may express higher levels of the lactate/monocarboxylate transporter than $\beta$-cells but lower ones of pyruvate carboxylase (Sekine et al. 1994, Zhao et al. 2001). These biochemical differences indicate that $\beta$-cells are more efficient in the mitochondrial oxidation of glucose, while $\alpha$-cells rely more on anaerobic glycolysis (Schuit et al. 1997, Quesada et al. 2006a). This lower coupling between glycolytic events in the cytosol and ATP synthesis in mitochondrial respiration of $\alpha$-cells would explain the fact that, in response to glucose, cytosolic ATP increases are small in these cells (Ishihara et al. 2003, Ravier \& Rutter 2005) and that ATP/ADP changes are almost invariable (Detimary et al. 1998). Therefore, some aspects at the above-mentioned models for $\boldsymbol{\alpha}$-cell stimulussecretion coupling deserve more attention, especially those concerning the modulation of $\mathrm{K}_{\mathrm{ATP}}$ channel activity by glucose metabolism and ATP production. Other mechanisms regulating $\mathrm{K}_{\text {ATP }}$ channels may also have an important role.

\section{Regulation of glucagon secretion by fatty acids and amino acids}

Although the lipotoxicity theory and its role in obesityinduced diabetes have increased the interest in the interactions between fatty acids and islet functions, little is known about their effect on the regulation of the $\alpha$-cell compared with those on $\beta$-cells. While initial studies suggested an inhibitory effect on glucagon secretion (Andrews et al. 1975), more recent investigations have indicated that short-term exposure to fatty acids stimulates the release of this hormone (Bollheimer $\mathrm{et}$ al. 2004, Olofsson et al. 2004, Hong et al. 2005). The short-term stimulatory action depends on the chain length, spatial configuration and degree of saturation of the fatty acid (Hong et al. 2005). The action of palmitate has been studied in mice at the cell level. This fatty acid increases $\boldsymbol{\alpha}$-cell exocytosis by enhancing $\mathrm{Ca}^{2+}$ entry through L-type $\mathrm{Ca}^{2+}$ channels and also, by relief of the inhibitory paracrine action of the somatostatin secreted from $\delta$-cells (Olofsson et al. 2004). A study using clonal $\alpha$-cells on the long-term effect of palmitate and oleate concluded that they also enhance glucagon secretion and triglyceride accumulation in a time- and dosedependent manner but inhibit cell proliferation (Hong et al. 2007). In agreement with this, the long-term exposure of rat islets to fatty acids induces a marked increase in glucagon release, a decrease in glucagon content and no changes in glucagon gene expression (Gremlich et al. 1997, Dumonteil et al. 2000). In addition to fatty acids, amino acids are also relevant in the modulation of the $\alpha$-cell function. Amino acids such as arginine, alanine and glutamine are potent stimulators of glucagon secretion (Pipeleers et al. 1985, Kuhara et al. 1991, Dumonteil et al. 2000). However, a few amino acids such as isoleucine can also inhibit $\boldsymbol{\alpha}$-cell secretion while leucine has a dual effect: it is a positive stimulus at physiological concentrations but becomes a negative one at elevated levels (15 mM; Leclercq-Meyer et al. 1985). In any case, the function of amino acids and fatty acids in the $\alpha$-cell requires further investigation at the cellular and molecular levels. 
Autocrine, paracrine, endocrine and neural regulation of glucagon secretion

Autocrine, paracrine and endocrine signalling The spatial distribution of $\alpha$-cells and the vascular organization within the islet sustain an important intercellular communication through autocrine and paracrine mechanisms (Fig. 3). In addition to insulin, glucagon or somatostatin, secretory granules from islet cells contain other molecules with biological activity, which are released to the extracellular space by exocytosis, activating surface receptors in the same cell, in neighbouring islet cells, or in distant cells within the islet via the vascular system. Several paracrine mechanisms are activated at high-glucose concentrations as a result of $\beta$ - and $\delta$-cell stimulations, and thus, they may participate in the glucose-induced inhibition of glucagon release.
Insulin and zinc. One of the most important paracrine mechanisms responsible for inhibiting glucagon release is conducted by insulin, acting via several pathways. An appropriate expression of the insulin receptor in mouse $\alpha$-cells seems to be essential for glucose-regulated glucagon secretion (Diao et al. 2005). In INR1-G9 clonal $\alpha$-cells, insulin has been found to inhibit glucagon release through the activation of phosphatidylinositol 3-kinase (PIK3; Kaneko et al. 1999). The insulin receptor-PIK3 signalling pathway is also involved in the modification of the sensitivity of $\mathrm{K}_{\mathrm{ATP}}$ channels to ATP in mouse $\alpha$-cells, which may affect the secretory response (Leung et al. 2006). Furthermore, insulin increases $K_{\text {ATP }}$ channel activity in isolated rat $\alpha$-cells, inducing an inhibitory effect on glucagon release via membrane hyperpolarization (Franklin et al. 2005). In addition to the effects on $\mathrm{K}_{\mathrm{ATP}}$ channels, insulin can translocate A-type GABA receptors to the cell membrane,

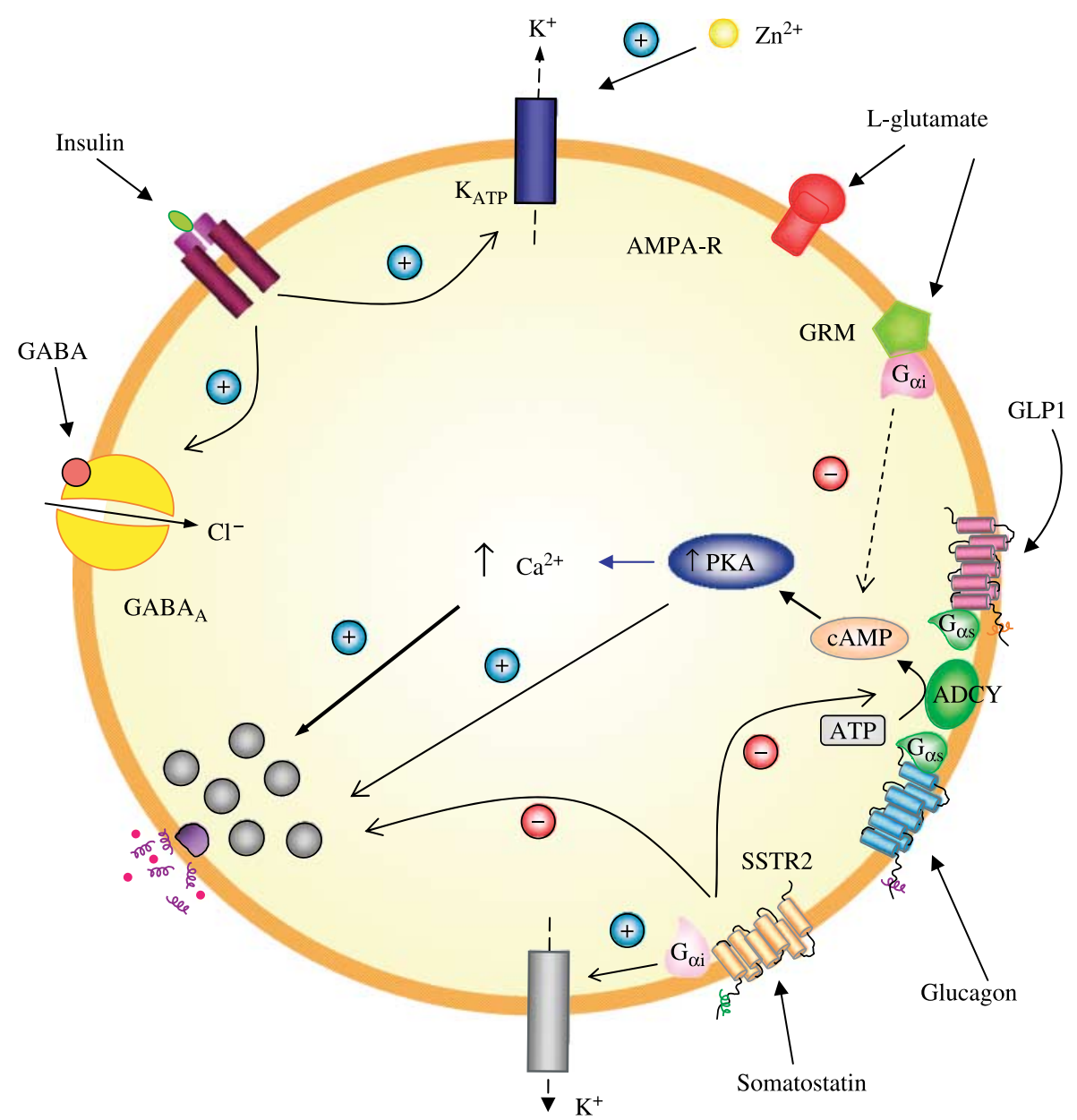

Figure 3 Paracrine signalling in the $\alpha$-cell. See text for details. ADCY, adenylate cyclase; AMPA-R, $\alpha$-amino-3-hydroxy-5-methyl-4-isoxazolepropionic acid receptor; GABA, $\gamma$-aminobutyric acid; GLP1, glucagon-like peptide-1; GRM, metabotrophic glutamate receptor; PKA, protein kinase A; SSTR2, somatostatin receptor-2. 
which increases the response to GABA secreted by $\beta$-cells, favouring membrane hyperpolarization and suppression of glucagon secretion (Xu et al. 2006). Since $\alpha$-cell $\mathrm{Ca}^{2+}$ signals rely on electrical activity, insulin also inhibits $\mathrm{Ca}^{2+}$ signals induced by low-glucose concentrations (Ravier \& Rutter 2005). Therefore, several pieces of evidence indicate that insulin inhibits glucagon release mainly by altering $\boldsymbol{\alpha}$-cell membrane potential.

Insulin is stored within the secretory granule forming stable hexamers around two atoms of $\mathrm{Zn}^{2+}$. After exocytosis, these hexameric crystals are exposed to a change in $\mathrm{pH}$ from $5 \cdot 5$ to $7 \cdot 4$, become dissociated and release both atoms of $\mathrm{Zn}^{2+}$. Recent studies have claimed that zinc atoms can also work as modulators of the $\alpha$-cell function (Gyulkhandanyan et al. 2008), although their role remains controversial. On one hand, it has been found that $\mathrm{Zn}^{2+}$ activates $\mathrm{K}_{\mathrm{ATP}}$ channels and decreases glucagon release in isolated rat $\alpha$-cells (Ishihara et al. 2003, Franklin et al. 2005). $\mathrm{Zn}^{2+}$ seems to be the switchoff signal to initiate glucagon secretion during hypoglycaemia in streptozotocin-induced diabetic rats (Zhou et al. 2007a). However, these results contrast with the absence of effects on mouse $\boldsymbol{\alpha}$-cells (Ravier \& Rutter 2005).

Somatostatin and glucagon Somatostatin is produced and secreted by several tissues in addition to the $\delta$-cell population of the islet and works as an inhibitor of both glucagon and insulin release (Fehmann et al. 1995). Immunocytochemical studies in human islets have demonstrated that, among the five identified somatostatin receptor (SSTR) subtypes, SSTR 2 is highly expressed in $\boldsymbol{\alpha}$-cells while SSTR 1 and SSTR 5 are expressed in $\beta$-cells (Kumar et al. 1999). In mice and rats, SSTR 2 also predominates in the $\alpha$-cell and SSTR 5 in the $\beta$-cell population (Hunyady et al. 1997, Strowski et al. 2000). These receptors are coupled to G-proteins and induce multiple intracellular effects. Electrophysiological studies have shown that somatostatin activates $\mathrm{K}^{+}$channels in $\boldsymbol{\alpha}$-cells, inducing membrane hyperpolarization and suppressing electrical activity, which affects $\mathrm{Ca}^{2+}$-dependent exocytosis (Yoshimoto et al. 1999, Gromada et al. 2001). Capacitance measurements have further elucidated that somatostatin directly decreases exocytosis by depriming secretory granules through the activation of the serine/threonine protein phosphatase calcineurin pathway (Gromada et al. 2001). Also, a negative interaction of somatostatin with adenylate cyclase and cAMP levels has been reported in rat $\alpha$-cells (Schuit et al. 1989). In addition to the effects of insulin and somatostatin on $\alpha$-cells, glucagon itself works as an extracellular messenger. It exerts an autocrine positive feedback that stimulates secretion in both isolated rat and mouse $\boldsymbol{\alpha}$-cells by an increase in exocytosis associated to a rise in cAMP levels (Ma et al. 2005).

GLP1 The incretin hormone glucagon-like peptide 1 (GLP1) is released from the L-cells of the small intestine after food intake, stimulating insulin production and inhibiting glucagon release. Because of this dual effect, GLP1 is a potential therapeutic agent in the treatment of diabetic patients that manifest insulin deficiency as well as hyperglucagonaemia (Dunning et al. 2005). The observed suppressing effect of GLP1 on glucagon secretion in vivo and in perfused pancreas contrasts with those effects found in single $\boldsymbol{\alpha}$-cells (Dunning et al. 2005). In isolated rat $\boldsymbol{\alpha}$-cells, GLP1 stimulates glucagon secretion by interacting with specific receptors coupled to G-proteins that activate adenylate cyclase, which increases cAMP levels (Ding et al. 1997, Ma et al. 2005). Thus, it seems that paracrine mechanisms may be responsible for the GLP1 suppressing action (Dunning et al. 2005). This possibility has been underscored by the findings in experiments using $\beta$-cell-specific knock-out mice for the transcription factor Pdx1. In these mice, the lack of effect of GLP1 on $\beta$-cells is also accompanied by its inability to induce an inhibitory action on glucagon plasma levels (Li et al. 2005). Moreover, GLP1 may also affect the $\alpha$-cell function by interacting with the autonomic nervous system (Balkan \& Li 2000).

Other extracellular messengers The neurotransmitter $\gamma$-aminobutyric acid (GABA) is another $\alpha$-cell modulator. GABA accumulates in $\beta$-cell vesicles and is released by $\mathrm{Ca}^{2+}$ dependent exocytosis, stimulating A-type GABA receptors in neighbouring $\alpha$-cells. Activation of these receptors is coupled to inward $\mathrm{Cl}^{-}$currents that hyperpolarize the $\boldsymbol{\alpha}$-cell plasma membrane, decreasing glucagon release in rats and guinea pigs (Rorsman et al. 1989, Wendt et al. 2004). Similar conclusions were obtained in mouse islets and clonal $\alpha \mathrm{TC} 1-9$ cells (Xu et al. 2006, Bailey et al. 2007). The neurotransmitter L-glutamate also accumulates in the $\alpha$-cell secretory granules because of vesicular glutamate transporters 1 and 2 found in these cells (Hayashi et al. 2003a). In low-glucose conditions, L-glutamate is cosecreted with glucagon, triggering GABA release from neighbouring $\beta$-cells and, subsequently, inhibiting the $\alpha$-cell function as previously described (Hayashi et al. 2003b). Additionally, glutamate can activate autocrine signalling pathways in $\boldsymbol{\alpha}$-cells through the multiple glutamate receptors expressed in these cells, which include ionotrophic AMPA and kainate subtypes and metabotrophic receptors (Inagaki et al. 1995, Uehara et al. 2004, Cabrera et al. 2008). Although activation of ionotrophic receptors may stimulate glucagon release (Bertrand et al. 1993), metabotrophic glutamate receptors inhibit rat glucagon secretion at low-glucose concentrations through a downregulation of cAMP levels (Uehara et al. 2004). Another $\alpha$-cell regulator is amylin or islet amyloid pancreatic polypeptide (Iapp). This polypeptide is a 37 amino acid hormone mainly synthesized in $\beta$-cells, although it can be produced in $\delta$-cells as well. This peptide is cosecreted with insulin by exocytosis and has an inhibitory effect on glucagon basal concentrations as well as on those levels observed after arginine stimulation (Akesson et al. 2003, Gedulin et al. 2006). This glucagonostatic effect has been reported in the plasma levels of mice and rats as well as in perfused pancreas or intact islets. Since amylin also reduces somatostatin and insulin release, some authors have proposed that endogen amylin within the islet may establish a negative feedback to avoid excessive secretion from $\alpha$-, $\beta$ - and $\delta$-cells (Wang et al. 1999). Also, the purinergic messenger ATP is highly accumulated in $\beta$-cell secretory granules and in nerve terminals. 
It has recently been reported that ATP inhibits $\mathrm{Ca}^{2+}$ signalling and glucagon secretion in mouse $\boldsymbol{\alpha}$-cells, indicating that purinergic receptors are involved in $\boldsymbol{\alpha}$-cell function (Tudurí et al. 2008). Purinergic regulation of glucagon release has also been described in rat islets (Grapengiesser et al. 2006).

Neural regulation As previously stated, the islet of Langerhans is highly innervated by parasympathetic and sympathetic nerves that ensure a rapid response to hypoglycaemia and protection from potential brain damage (Ahren 2000). Some terminals of these nerves store and release classical neurotransmitters, such as acetylcholine and noradrenaline, as well as several neuropeptides, which stimulate or inhibit glucagon secretion depending on the neural messenger released. Cholinergic stimulation involving muscarinic receptors and intracellular $\mathrm{Ca}^{2+}$ mobilization enhances $\alpha$-cell function both in vivo and in isolated cells (Ahren \& Lundquist 1982, Berts et al. 1997). Noradrenaline increases glucagon secretion as well (Ahren et al. 1987). Sympathetic activation can also induce adrenaline release from the adrenal medulla, which potently stimulates glucagon secretion by enhancing $\mathrm{Ca}^{2+}$ influx through L-type $\mathrm{Ca}^{2+}$ channels and accelerating granule mobilization (Gromada et al. 1997). In addition to classical neurotransmitters, several neuropeptides such as vasoactive intestinal polypeptide, pituitary adenylate cyclase-activating polypeptide and gastrin-releasing peptide, which may stimulate glucagon release from pancreas, can be accumulated in parasympathetic nerves, while galanin and neuropeptide $\mathrm{Y}$ can be stored in sympathetic nerve terminals (Ahren 2000). Multiple actions have been reported for the latter neuropeptides. The effects and mechanisms involved in neural regulation of $\alpha$-cells have yet to be established at the cellular and molecular levels. These systems are mainly regulated by glucose-sensing neurons of the ventromedial hypothalamus, which respond to plasma glucose levels with mechanisms very similar to those of the $\beta$-cell, including the activity of glucoseregulated $\mathrm{K}_{\text {АTP }}$ channels (Borg et al. 1994, Miki et al. 2001, Song et al. 2001). Actually, it has been observed that the $\alpha$-cell response to hypoglycaemia is also impaired in KCNJ11deficient mice whose neurons of the ventromedial hypothalamus lack functional $\mathrm{K}_{\mathrm{ATP}}$ channels and glucose responsiveness (Miki et al. 2001).

\section{Glucagon physiological and pathophysiological actions and its role in diabetes}

\section{Glucagon synthesis}

The preproglucagon-derived peptides glucagon, GLP1 and GLP2, are encoded by the preproglucagon gene, which is expressed in the central nervous system, intestinal L-cells and pancreatic $\alpha$-cells. A post-translational cleavage by prohormone convertases $(\mathrm{PC})$ is responsible for the maturation of the preproglucagon hormone that generates all these peptides (Mojsov et al. 1986). The different expression of PC subtypes in each tissue mediates the production of each different peptide. In $\boldsymbol{\alpha}$-cells, the predominance of PCSK2 leads to a major production of glucagon together with the products glicentin, glicentin-related pancreatic polypeptide, intervening peptide 1 and the major proglucagon fragment (Dey et al. 2005). The absence of PCSK2 in knock-out mice leads to a lack of mature glucagon (Furuta $e t$ al. 2001). In enteroendocrine cells, PCSK1/3 enzymes cleave the preproglucagon hormone to generate GLP1 and GLP2 along with glicentin, intervening peptide 2 and oxyntomodulin (Mojsov et al. 1986).

The regulation of glucagon gene expression has not been studied as extensively as the insulin gene. The inhibitory effect of insulin on glucagon secretion has also been confirmed in gene expression and it occurs at the transcriptional level (Philippe et al. 1995). In diabetic rats, glucagon gene expression is augmented and is accompanied by hyperglucagonaemia in conditions of hyperglycaemia and insulin deficiency. Insulin treatment normalized glucagon expression and plasma levels in these rats, an effect that was not attributed to the restoration of normal glucose levels (Dumonteil et al. 1998). It was concluded that insulin, unlike glucose, modulates glucagon expression. The lack of response to glucose was further confirmed in isolated rat islets (Gremlich et al. 1997, Dumonteil et al. 2000), contrasting with the up-regulation of glucagon expression observed in clonal $\boldsymbol{\alpha}$-cells (Dumonteil et al. 1999, McGirr et al. 2005). The effect of amino acids on glucagon gene regulation has also been studied. While arginine increases glucagon expression in isolated rat islets: a process that is mediated by protein kinase C (PKA; Yamato et al. 1990, Dumonteil et al. 2000), histidine plays a fundamental role in clonal $\alpha \mathrm{TC} 1-6$ cells (Paul et al. 1998). Other nutrients, such as the fatty acid palmitate, produces a down-regulated glucagon expression at short term in rat islets in a dose-dependent manner (Bollheimer et al. 2004). By contrast, no effect with palmitate has been observed in other long-term studies (Gremlich et al. 1997, Dumonteil et al. 2000). Like insulin, somatostatin also inhibits glucagon expression. It has been reported that somatostatin downregulates glucagon expression basal levels as well as those produced by forskolin stimulation in clonal INR1G9 cells (Fehmann et al. 1995, Kendall et al. 1995).

\section{Glucagon receptor}

The rat and mouse glucagon receptor is a 485 amino acid protein, belonging to the secretin-glucagon receptor II class family of G protein-coupled receptors (Mayo et al. 2003). Glucagon binding to this receptor is coupled to GTP-binding heterotrimeric $G$ proteins of the $G \alpha_{s}$ type that leads to the activation of adenylate cyclase, cAMP production and PKA. This receptor can also activate the phospholipase C/inositol phosphate pathway via $\mathrm{G}_{\mathrm{q}}$ proteins, resulting in $\mathrm{Ca}^{2+}$ release from intracellular stores (Fig. 4; Wakelam et al. 1986, Mayo et al. 2003). The glucagon receptor is present in multiple tissues including the liver, pancreas, heart, kidney, brain and 


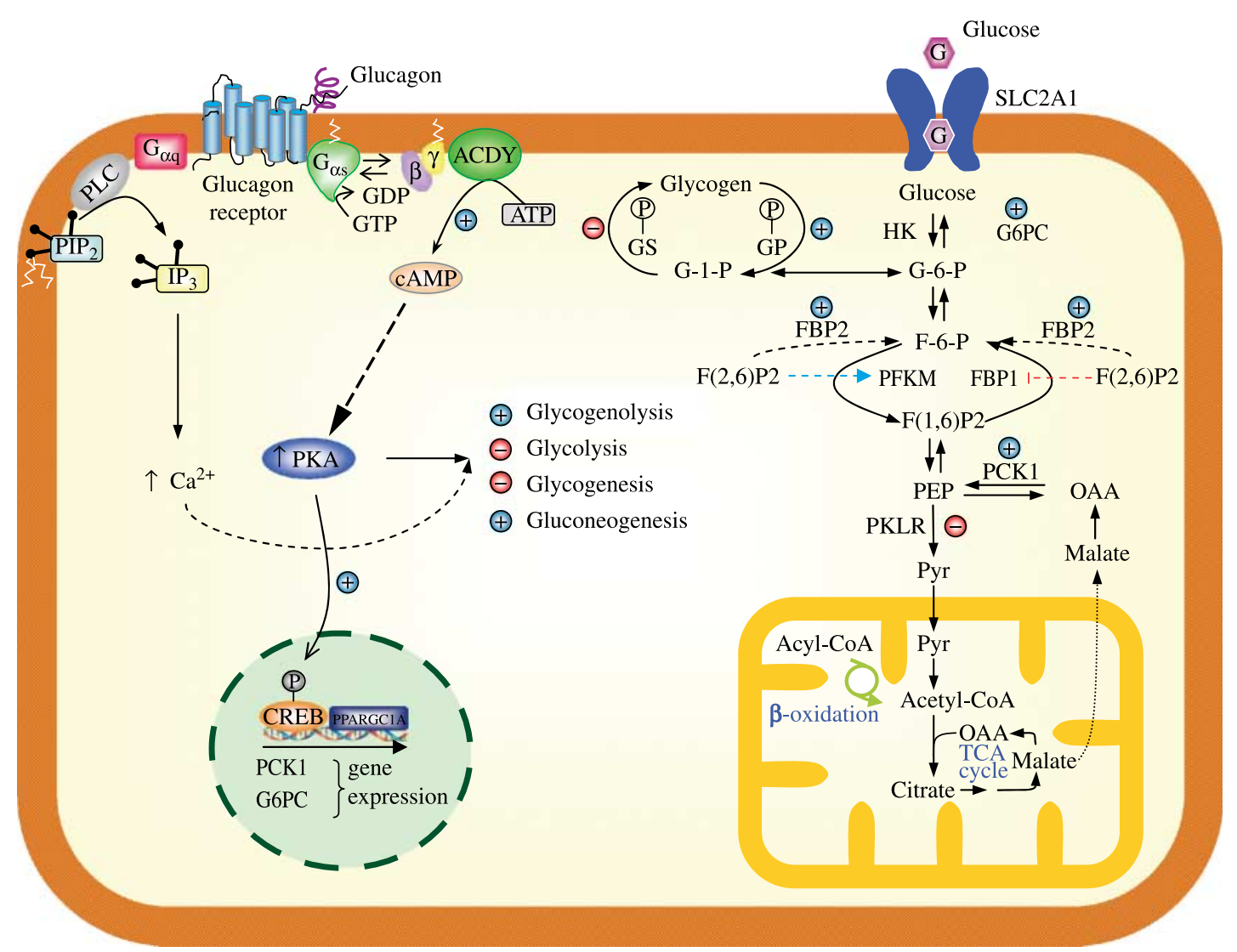

Figure 4 The role of glucagon and the glucagon receptor in the liver. Glucagon signalling regulates positively $(+)$ or negatively $(-)$ the multiple steps of the hepatic glucose metabolism. This modulation affects the expression and/or the activity of several enzymes of glucose metabolism. See text for details. ADCY, Adenylate cyclase; CREB, cAMP response element binding; $F(1,6) P 2$, fructose-1,6-bisphosphate; $F(2,6) P 2$, fructose-2,6-bisphosphate; $F-6$ - $P$, fructose 6-phosphate; FBP1, fructose-1,6-bisphosphatase; FBP2, fructose-2,6-bisphosphatase; G-1-P, glucose 1-phosphate; G-6-P, glucose 6-phosphate; G6PC, glucose-6-phosphatase; GP, glycogen phosphorylase; GS, glycogen synthase; IP3, inositol 1,4,5-trisphosphate; OAA, oxaloacetate; PC, pyruvate carboxylase; PEP, phosphoenolpyruvate; PCK2, phosphoenolpyruvate carboxykinase; PFKM, phosphofructokinase-1; PPARGC1A, peroxisome proliferators-activated receptor- $\gamma$ coactivator-1; PIP2, phosphatidylinositol 4,5-bisphosphate; PKLR, pyruvate kinase; PLC, phospholipase C; Pyr, pyruvate. Dashed lines: red, inhibition; blue, stimulation.

smooth muscle. Thus, it modulates multiple responses in these tissues, including effects on ion transport and glomerular filtration rate in kidney among others (Ahloulay et al. 1992). In any case, the regulation of glucose homeostasis is the major function of glucagon and its receptor. This role will be described in the next paragraph.

\section{Glucagon control of glucose homeostasis and metabolism}

Several lines of defence protect the organism against hypoglycaemia and its potential damaging effects, especially in the brain, which depends on a continuous supply of glucose, its principal metabolic fuel. These defences include decreased insulin release and increased secretion of adrenaline and glucagon. Additionally, glucose-sensing neurons of the ventromedial hypothalamus further control responses to glycaemia changes, as previously mentioned. Among all these regulatory systems, glucagon plays a central role in the response to hypoglycaemia and also opposes to insulin effects. The main action of glucagon occurs in the liver where the insulin/glucagon ratio controls multiple steps of hepatic metabolism. Glucagon stimulates gluconeogenesis and glycogenolysis, which increases hepatic glucose output, ensuring an appropriate supply of glucose to body and brain, and at the same time, it decreases glycogenesis and glycolysis. The glucagon receptor in the liver is highly selective for glucagon, but it exhibits a modest affinity for glucagon-like peptides (Hjorth et al. 1994). Its main action on the liver is mediated by the activation of adenylyl cyclase and the PKA pathway. Glucagon regulates gluconeogenesis mainly by the up-regulation of key enzymes such as glucose-6-phosphatase (G6PC) and phosphoenolpyruvate carboxykinase (PCK2) through the 
activation of the cAMP response element-binding protein (CREB) and peroxisome proliferator-activated receptor $\gamma$-coactivator-1 (PPARGC1A; Herzig et al. 2001, Yoon et al. 2001; Fig. 4). PCK2 and G6PC, along with fructose1,6-biphosphatase (FBP1) have a key role in the rate of gluconeogenesis (Fig. 4). PCK2 mediates the conversion of oxalacetate into phosphoenolpyruvate while G6PC regulates glucose production from glucose-6-phosphate. FBP1 is responsible for the conversion of fructose-1,6-biphosphate $(\mathrm{F}(1,6) \mathrm{P} 2)$ into fructose-6-phosphate $(\mathrm{F} 6 \mathrm{P})$. Its activity is regulated by glucagon since this hormone decreases the intracellular levels of fructose-2,6-biphosphate $(\mathrm{F}(2,6) \mathrm{P} 2)$, an allosteric inhibitor of FBP1 (Kurland \& Pilkis 1995). Additionally, this decrease in $\mathrm{F}(2,6) \mathrm{P} 2$ also reduces the activity of phosphofructokinase-1 (PFKM), down-regulating glycolysis. The glycolytic pathway is further inhibited by glucagon at the pyruvate kinase (PKLR) level (Slavin et al. 1994). Glycogen metabolism is mainly determined by the activity of glycogen synthase (GS) and glycogen phosphorylase (GP). While glucagon is important for GP phosphorylation and activation, it inhibits GS function by phosphorylation and its conversion into an inactive form of the enzyme (Band \& Jones 1980, Ciudad et al. 1984, Andersen et al. 1999).

Glucagon can also stimulate the uptake of amino acids for gluconeogenesis in the liver. Indeed, subjects with hyperglucagonaemia can develop plasma hypoaminoacidaemia, especially of amino acids involved in gluconeogenesis, such as alanine, glycine and proline (Cynober 2002). Glucagon is also involved in the regulation of fatty acids in adipocytes. Hormone-sensitive lipase mediates the lipolysis of triacylglycerol into the non-esterified fatty acids and glycerol, which are released from adipocytes. It has been reported that although glucagon does not modify the transcriptional levels of this enzyme, it increases the release of glycerol from adipocytes (Slavin et al. 1994). This mobilization of glycerol from adipose tissue can further be used in the liver during gluconeogenesis. However, the existence of a lipolytic action of glucagon observed in several animal models is still controversial in humans. While a positive effect of glucagon on lipolysis has been reported in human subjects (Carlson et al. 1993), several recent studies have indicated that it lacks a role in a physiological context (Gravholt et al. 2001). An elevated glucagon to insulin ratio accelerates gluconeogenesis as well as fatty acid $\beta$-oxidation and ketone bodies formation (Vons et al. 1991). Thus, glucagon may also be involved in diabetic ketoacidosis, a medical complication in diabetes derived from the overproduction of ketone bodies (Eledrisi et al. 2006).

\section{The role of $\alpha$-cell function in diabetes}

More than 30 years ago, Unger \& Orci (1975) proposed the bihormonal hypothesis to explain the pathophysiology of diabetes. According to this hypothesis, this metabolic disease is the result of an insulin deficiency or resistance along with an absolute or relative excess of glucagon, which can cause a higher rate of hepatic glucose production than glucose utilization, favouring hyperglycaemia. At present, there exists multiple clinical and experimental evidence that support this hypothesis. The rate of hepatic glucose output has been correlated with the hyperglycaemia found in animal models of diabetes as well as in human diabetes, and the maintenance of this abnormality has also been associated with hyperglucagonaemia (Baron et al. 1987, Consoli et al. 1989, Gastaldelli et al. 2000, Dunning \& Gerich 2007, Li et al. 2008). In type 2 diabetes, the impairment of insulin release and development of insulin resistance is often accompanied by absolute or relative increased levels of glucagon in the fasting and postprandial states (Reaven et al. 1987, Larsson \& Ahren 2000). In this situation, insulin is not effective as a negative feedback for hepatic glucose output while glucagon potentiates glucose mobilization from the liver, thus contributing to hyperglycaemia. Another malfunction reported in diabetic patients is the lack of suppression of glucagon release in hyperglycaemic conditions, which would contribute further to postprandial hyperglycaemia in both type 1 and type 2 diabetes (Dinneen et al. 1995, Shah et al. 2000). However, this irregular $\boldsymbol{\alpha}$-cell behaviour does not occur when insulin levels are adequate, suggesting that abnormalities in glucagon release are relevant for hyperglycaemia in the context of diabetes or impairment of insulin secretion or action (Shah et al. 1999). Hyperglucagonaemia is also responsible for the development of hyperglycaemia and diabetes in patients with the glucagonoma syndrome, a paraneoplastic phenomenon characterized by an islet $\alpha$-cell pancreatic tumour (Chastain 2001).

Another defect in normal glucagon secretion has important consequences in the management of hypoglycaemia. The secretory response of $\boldsymbol{\alpha}$-cells to low-glucose concentrations is impaired in type 1 and long-lasting type 2 diabetes, increasing the risk of episodes of severe hypoglycaemia, especially in patients treated with insulin (Cryer 2002). In this regard, iatrogenic hypoglycaemia is a situation that implies insulin excess and compromised glucose counter-regulation, and it is responsible for a major complication in diabetes treatment, increasing the morbidity and mortality of this disease (Cryer 2002). This lack of glucagon response to hypoglycaemia has been associated with multiple failures in $\alpha$-cell regulation; yet, the mechanisms are still under study (Bolli et al. 1984, Cryer 2002, Zhou et al. 2007b). Even though islet allotransplantation can provide prolonged insulin independence in patients with type 1 diabetes, the lack of $\alpha$-cell response to hypoglycaemia usually persists after transplantation, indicating that this procedure does not restore the physiological behaviour of $\alpha$-cells (Paty et al. 2002).

All these problems in the glucagon secretory response observed in diabetes have been attributed to several defects in $\alpha$-cell regulation including defective glucose sensing, loss of $\beta$-cell function, insulin resistance or autonomic malfunction. However, the mechanisms involved in $\boldsymbol{\alpha}$-cell pathophysiology still remain largely unknown and deserve more investigation for better design of therapeutic strategies. In this regard, 
although direct therapeutic approaches to correct the lack of $\boldsymbol{\alpha}$-cell response to hypoglycaemia are missing, several proposals have been developed to amend glucagon excess, as we will see in the next section.

\section{Molecular pharmacology of glucagon release and action: therapeutic potential in diabetes treatment}

Given that absolute or relative glucagon excess seems to be critical in the development and/or maintenance of hyperglycaemia in diabetes by increasing hepatic glucose output, the strategies targeted to correct this malfunction are suitable for the improvement of glucose levels. In this respect, several experimental and therapeutic approaches have been developed (for a further review, see Dunning \& Gerich 2007). The specific control of glucagon secretion by pharmacological modulation is complex since several components of the $\alpha$-cell stimulus-secretion coupling are also present in $\beta$ - and $\delta$-cells. Thus, the manipulation of glucagon action by modulating the glucagon receptor signalling seems to be an effective alternative ( $\mathrm{Li}$ et al. 2008). This strategy has been supported by several studies. Glucagon receptor knock-out mice have hyperglucagonaemia and $\alpha$-cell hyperplasia, but their glucose tolerance is improved and they develop only a mild fasting hypoglycaemia (Gelling et al. 2003). These mice have a normal body weight, food intake and energy expenditure although less adiposity and lower leptin levels. These results are consistent with the experiments with anti-sense oligonucleotides for the glucagon receptor. Diabetic $\mathrm{db} / \mathrm{db}$ mice treated with these oligonucleotides had lower glucose, triglyceride and free fatty acids blood levels, as well as improved glucose tolerance, and they developed hyperglucagonaemia without apparent effects on $\alpha$-cell size or number (Liang et al. 2004). This approach is also accompanied by an increase in GLP1 and insulin levels in Zucker diabetic fatty rats and $\mathrm{db} / \mathrm{db}$ and ob/ ob mice (Sloop et al. 2004). Furthermore, the use of high affinity, neutralizing glucagon monoclonal antibodies improved glycaemic control and reduced hepatic glucose production in diabetic ob/ob mice (Sorensen et al. 2006). Therefore, these experimental results are a further support that glucagon antagonism may be beneficial for diabetes treatment.

\section{Modulation of glucagon secretion}

Sulphonylureas Sulphonylureas are efficient $\mathrm{K}_{\text {ATP }}$ channel blockers that have been extensively used for the clinical treatment of diabetes. In rat $\alpha$-cells, sulphonylureas stimulate electrical activity, $\mathrm{Ca}^{2+}$ signalling and glucagon release (Franklin et al. 2005). In mice, however, tolbutamide produces membrane depolarization, but a decrease in $\mathrm{Ca}^{2+}$ signalling and glucagon release (Gromada et al. 2004). Recent experiments in mouse $\alpha$-cells have shown that, in the absence of glucose, this drug increases glucagon secretion at concentrations up to $1 \mu \mathrm{M}$, but higher doses are inhibitory (MacDonald et al. 2007). This biphasic effect is due to the mouse $\boldsymbol{\alpha}$-cell electrical behaviour (Fig. 1): glucagon release takes place within a narrow window of intermediate $\mathrm{K}_{\text {ATP }}$ channel activity (and membrane potential), and thus it is inhibited when the cell is hyperpolarized or depolarized beyond this membrane potential range (MacDonald et al. 2007). Accordingly, with this scheme, the $\mathrm{K}_{\text {ATP }}$ channel opener diazoxide can also have a biphasic effect on glucagon secretion. These effects will change depending on the extracellular glucose concentrations that necessarily influence $\mathrm{K}_{\text {ATP }}$ channel activity (MacDonald et al. 2007). This biphasic behaviour may explain the disparity of effects found for sulphonylureas (Loubatieres et al. 1974, Ostenson et al. 1986). In humans, sulphonylureas are associated to a glucagon secretion decrease in healthy and type 2 diabetic subjects (Landstedt-Hallin et al. 1999), while they stimulate glucagon levels in type 1 diabetic patients (Bohannon et al. 1982). Since sulphonylureas also induce insulin and somatostatin secretion, which affect $\alpha$-cells, these drugs offer a poor specific control of glucagon secretion.

GLP1 mimetics and DPP4 inhibitors In addition to stimulating insulin release, GLP1 can suppress glucagon secretion in humans, perfused rat pancreas and isolated rat islets in a glucose-dependent manner (Guenifi et al. 2001, Nauck et al. 2002). Because GLP1 is rapidly cleaved and inactivated by the enzyme dipeptidyl peptidase-IV (DPP4), a good alternative would be to design either GLP1 derivatives with higher resistance to DPP4 or agents that increase GLP1 endogenous levels. Among the GLP1 mimetics, exenatide is a synthetic polypeptide with high resistance to DPP4 cleavage that decreases glucagon levels in normal and diabetic subjects (Degn et al. 2004). Liraglutide, another GLP1 derivative with long-lasting actions, can reduce glucagon release after a meal in patients with type 2 diabetes (Juhl et al. 2002). Alternatively, DPP4 inhibitors like sitagliptin and vildagliptin increase the endogen effects of GLP1, reducing glucagon plasma concentrations in diabetic individuals (Rosenstock et al. 2007). Since all these alternatives produce opposing actions on insulin and glucagon, they generate promising expectations for diabetes treatment.

Imidazolines The insulinotrophic effects of imidazoline compounds are mediated by $\mathrm{K}_{\text {ATP }}$ channel blockade, which leads to depolarization, $\mathrm{Ca}^{2+}$ influx and secretion, and by direct interactions with the exocytotic machinery (Zaitsev et al. 1996). Remarkably, imidazoline compounds such as phentolamine also suppress glucagon secretion in both rat and mouse islets, an action mediated by a direct effect on $\boldsymbol{\alpha}$-cell exocytosis via activation of phosphatase calcineurin proteins, and independent of $\mathrm{K}_{\mathrm{ATP}}$ channels or $\mathrm{Ca}^{2+}$ currents (Hoy et al. 2001). Given that imidazoline compounds stimulate insulin release while inhibiting glucagon secretion, these drugs are potentially valuable in diabetes. 
Somatostatin analogues Because of the different expression of SSTR in the islet (Kumar et al. 1999), several studies have explored the modulation of glucagon secretion by subtype-specific somatostatin analogues (Strowski et al. 2006). It has been shown that SSTR 2 is the subtype receptor predominantly expressed in rodent $\alpha$-cells, and that SSTR2deficient mice develop hyperglycaemia and non-fasting hyperglucagonaemia (Singh et al. 2007). In mice, the use of a highly SSTR2-selective non-peptide agonist inhibited glucagon release without affecting insulin release (Strowski et al. 2006). However, there is some overlapping in human islets between the different SSTR subtypes in $\alpha$ - and $\beta$-cells that limit, at present, the use of subtype-specific somatostatin analogues (Singh et al. 2007).

Amylin and pramlintide Amylin, which is cosecreted with insulin from $\beta$-cells, inhibits glucagon secretion stimulated by amino acids but does not affect hypoglycaemia-induced glucagon release (Young 2005). Since $\alpha$-cell response to amino acids is often exaggerated in diabetic patients, amylin or amylinomimetic compounds such as pramlintide are used as an effective alternative for the treatment of postprandial and amino acid-induced excess of glucagon secretion (Dunning et al. 2005, Young 2005).

\section{Modulation of glucagon action and glucagon receptor signalling}

Peptide-based glucagon receptor antagonists Several linear and cyclic glucagon analogues have been developed to work as glucagon receptor antagonists. Essentially, they impair the ability of glucagon to stimulate adenylate cyclase activity in liver, thus reducing hepatic glucose output and improving plasma glucose levels. This is the case of [des-His ${ }^{1}$, des-Phe ${ }^{6}$, Glu ${ }^{9}$ glucagon- $\mathrm{NH}_{2}$, which reduces glucose levels in streptozotocin-induced diabetic rats (Van Tine et al. 1996). Recent investigations have demonstrated that the antagonist des-His-glucagon binds preferentially to the hepatic glucagon receptor in vivo, and this correlates with the glucose lowering effects (Dallas-Yang et al. 2004).

Non-peptide glucagon receptor antagonists Multiple, competitive and non-competitive, non-peptide antagonists have been reported to act on glucagon binding and/or function. For instance, a novel competitive antagonist (N-[3-cyano-6-(1, 1-dimethylpropyl)-4, 5, 6, 7-tetrahydro1-benzothien-2-yl]-2-ethylbutanamide) was recently shown to inhibit glucagon-mediated glycogenolysis in primary human hepatocytes and to block the increase in glucose levels after the administration of exogenous glucagon in mice (Qureshi et al. 2004). The information about the effect of these antagonists on humans is, however, scarce. In this respect, Bay 27-9955 is an oral glucagon receptor antagonist that has been tested in humans, demonstrating its efficacy in reducing glucose levels induced by exogenous glucagon (Petersen \& Sullivan 2001).
Despite the success of several approaches to modulate glucagon secretion or action and improve glucose control in animal models or in humans, more information is still required. Long-standing studies should address whether the utilization of these agents could lead to undesired hypoglycaemia in humans, accumulation of lipids or compensatory mechanisms that decrease the benefits of these therapies in the long term. In this aspect, the results obtained in animal models are positive: although the glucagon receptor knock-out mouse develops hyperglucagonaemia, it is not hypoglycaemic and does not have an abnormal accumulation of lipids (Gelling et al. 2003). Additionally, recent long-term studies in mice further prove the viability of glucagon antagonism (Winzell et al. 2007). Thus, present data are promising and indicate that several therapeutic agents targeted to glucagon signalling and $\alpha$-cell secretion may be useful for the management of diabetes.

\section{Conclusions}

Pancreatic $\alpha$-cells and glucagon secretion are fundamental components of the regulatory mechanisms that control glucose homeostasis. However, $\boldsymbol{\alpha}$-cell physiology has remained elusive compared with the overwhelming information about insulin secretion and the $\beta$-cell. In recent years, however, several groups have initiated intensive efforts to understand $\alpha$-cell physiology and identified essential pieces of its stimulus-secretion coupling. Additionally, important aspects of the regulation of $\alpha$-cell metabolism and the control of glucagon expression are being elucidated. All of this information will favour an overall comprehension of the $\alpha$-cell function and its role in glucose homeostasis. Nevertheless, more research is required to understand the $\alpha$-cell behaviour, not only in healthy subjects but in pathological conditions as well. In conclusion, since the malfunction of the glucagon secretory response is involved in diabetes and its complications, a complete understanding of the $\alpha$-cell will allow for a better design of therapeutic approaches for the treatment of this disease.

\section{Declaration of interest}

The authors declare that there is no conflict of interest that could be perceived as prejudicing the impartiality of the research reported.

\section{Funding}

This work was supported by grants from the Ministerio de Educación y Ciencia (BFU2007-67607 and PCI2005-A7-0131 to I Q; BFU2005-01052 to A N). CIBERDEM is an initiative of the Instituto de Salud Carlos III.

\section{References}

Ahloulay M, Bouby N, Machet F, Kubrusly M, Coutaud C \& Bankir L 1992 Effects of glucagon on glomerular filtration rate and urea and water excretion. American Journal of Physiology. Renal Physiology 263 F24-F36. 
Ahren B 2000 Autonomic regulation of islet hormone secretion implications for health and disease. Diabetologia 43 393-410.

Ahren B \& Lundquist I 1982 Influences of gastro-intestinal polypeptides and glucose on glucagon secretion induced by cholinergic stimulation. Hormone and Metabolic Research 14 529-532.

Ahren B, Veith RC \& Taborsky GJ Jr 1987 Sympathetic nerve stimulation versus pancreatic norepinephrine infusion in the dog: 1). Effects on basal release of insulin and glucagon. Endocrinology 121 323-331.

Akesson B, Panagiotidis G, Westermark P \& Lundquist I 2003 Islet amyloid polypeptide inhibits glucagon release and exerts a dual action on insulin release from isolated islets. Regulatory Peptides 111 55-60.

Andersen B, Rassov A, Westergaard N \& Lundgren K 1999 Inhibition of glycogenolysis in primary rat hepatocytes by 1, 4-dideoxy-1,4-iminoD-arabinitol. Biochemical Journal 342 545-550.

Andrews SS, Lopez-S A \& Blackard WG 1975 Effect of lipids on glucagon secretion in man. Metabolism 24 35-44.

Asplin C, Raghu P, Dornan T \& Palmer JP 1983 Glucose regulation of glucagon secretion independent of B cell activity. Metabolism 32 292-295.

Bailey SJ, Ravier MA \& Rutter GA 2007 Glucose-dependent regulation of gamma-aminobutyric acid (GABA A) receptor expression in mouse pancreatic islet alpha-cells. Diabetes 56 320-327.

Balkan B \& Li X 2000 Portal GLP-1 administration in rats augments the insulin response to glucose via neuronal mechanisms. American Journal of Physiology. Regulatory, Integrative and Comparative Physiology 279 R1449-R1454.

Band GC \& Jones CT 1980 Functional activation by glucagon of glucose 6-phosphatase and gluconeogenesis in the perfused liver of the fetal guinea pig. FEBS Letters 119 190-194.

Barg S, Galvanovskis J, Gopel SO, Rorsman P \& Eliasson L 2000 Tight coupling between electrical activity and exocytosis in mouse glucagonsecreting alpha-cells. Diabetes 49 1500-1510.

Baron AD, Schaeffer L, Shragg P \& Kolterman OG 1987 Role of hyperglucagonemia in maintenance of increased rates of hepatic glucose output in type II diabetics. Diabetes 36 274-283.

Bertrand G, Gross R, Puech R, Loubatieres-Mariani MM \& Bockaert J 1993 Glutamate stimulates glucagon secretion via an excitatory amino acid receptor of the AMPA subtype in rat pancreas. European Journal of Pharmacology 237 45-50.

Berts A, Gylfe E \& Hellman B 1997 Cytoplasmic $\mathrm{Ca}^{2+}$ in glucagonproducing pancreatic alpha-cells exposed to carbachol and agents affecting $\mathrm{Na}^{+}$fluxes. Endocrine 6 79-83.

Bohannon NV, Lorenzi M, Grodsky GM \& Karam JH 1982 Stimulatory effects of tolbutamide infusion on plasma glucagon in insulin-dependent diabetic subjects. Journal of Clinical Endocrinology and Metabolism 54 459-462.

Bokvist K, Olsen HL, Hoy M, Gotfredsen CF, Holmes WF, Buschard K, Rorsman P \& Gromada J 1999 Characterisation of sulphonylurea and ATPregulated $\mathrm{K}^{+}$channels in rat pancreatic A-cells. Pflugers Archiv: European Journal of Physiology 438 428-436.

Bollheimer LC, Landauer HC, Troll S, Schweimer J, Wrede CE, Scholmerich J \& Buettner R 2004 Stimulatory short-term effects of free fatty acids on glucagon secretion at low to normal glucose concentrations. Metabolism $\mathbf{5 3}$ 1443-1448

Bolli GB, Tsalikian E, Haymond MW, Cryer PE \& Gerich JE 1984 Defective glucose counterregulation after subcutaneous insulin in noninsulindependent diabetes mellitus. Paradoxical suppression of glucose utilization and lack of compensatory increase in glucose production, roles of insulin resistance, abnormal neuroendocrine responses, and islet paracrine interactions. Journal of Clinical Investigation 73 1532-1541.

Bonner-Weir S 1991 Anatomy of the islet of Langerhans. In The Endocrine Pancreas, pp 15-28. Ed. E Samols. New York: Raven Press.

Borg WP, During MJ, Sherwin RS, Borg MA, Brines ML \& Shulman GI 1994 Ventromedial hypothalamic lesions in rats suppress counterregulatory responses to hypoglycemia. Journal of Clinical Investigation 93 1677-1682.

Brelje TC, Scharp DW \& Sorenson RL 1989 Three-dimensional imaging of intact isolated islets of Langerhans with confocal microscopy. Diabetes 38 808-814.
Brissova M, Fowler MJ, Nicholson WE, Chu A, Hirshberg B, Harlan DM \& Powers AC 2005 Assessment of human pancreatic islet architecture and composition by laser scanning confocal microscopy. Journal of Histochemistry and Cytochemistry 53 1087-1097.

Cabrera O, Berman DM, Kenyon NS, Ricordi C, Berggren PO \& Caicedo A 2006 The unique cytoarchitecture of human pancreatic islets has implications for islet cell function. PNAS 103 2334-2339.

Cabrera O, Jacques-Silva MC, Speier S, Yang SN, Köhler M, Fachado A, Vieira E, Zierath JR, Kibbey R, Berman DM et al. 2008 Glutamate is a positive autocrine signal for glucagon release. Cell Metabolism 7 545-554.

Carlson MG, Snead WL \& Campbell PJ 1993 Regulation of free fatty acid metabolism by glucagon. Journal of Clinical Endocrinology and Metabolism 77 11-15.

Chastain MA 2001 The glucagonoma syndrome: a review of its features and discussion of new perspectives. American Journal of the Medical Sciences 321 306-320

Ciudad C, Camici M, Ahmad Z, Wang Y, DePaoli-Roach AA \& Roach PJ 1984 Control of glycogen synthase phosphorylation in isolated rat hepatocytes by epinephrine, vasopressin and glucagon. European Journal of Biochemistry 142 511-520.

Consoli A, Nurjhan N, Capani F \& Gerich J 1989 Predominant role of gluconeogenesis in increased hepatic glucose production in NIDDM. Diabetes 38 550-557.

Cryer PE 2002 Hypoglycaemia: the limiting factor in the glycaemic management of Type I and Type II diabetes. Diabetologia 45 937-948.

Cynober LA 2002 Plasma amino acid levels with a note on membrane transport: characteristics, regulation, and metabolic significance. Nutrition 18 761-766.

Dallas-Yang Q, Shen X, Strowski M, Brady E, Saperstein R, Gibson RE, Szalkowski D, Qureshi SA, Candelore MR, Fenyk-Melody JE et al. 2004 Hepatic glucagon receptor binding and glucose-lowering in vivo by peptidyl and non-peptidyl glucagon receptor antagonists. European Journal of Pharmacology $501225-234$.

Degn KB, Brock B, Juhl CB, Djurhuus CB, Grubert J, Kim D, Han J, Taylor K, Fineman M \& Schmitz O 2004 Effect of intravenous infusion of exenatide (synthetic exendin-4) on glucose-dependent insulin secretion and counterregulation during hypoglycemia. Diabetes 53 2397-2403.

Detimary P, Dejonghe S, Ling Z, Pipeleers D, Schuit F \& Henquin JC 1998 The changes in adenine nucleotides measured in glucose-stimulated rodent islets occur in beta cells but not in alpha cells and are also observed in human islets. Journal of Biological Chemistry 273 33905-33908.

Dey A, Lipkind GM, Rouille Y, Norrbom C, Stein J, Zhang C, Carroll R \& Steiner DF 2005 Significance of prohormone convertase 2, PC2, mediated initial cleavage at the proglucagon interdomain site, Lys70-Arg71, to generate glucagon. Endocrinology 146 713-727.

Diao J, Asghar Z, Chan CB \& Wheeler MB 2005 Glucose-regulated glucagon secretion requires insulin receptor expression in pancreatic $\alpha$-cells. Journal of Biological Chemistry 280 33487-33496.

Ding WG, Renstrom E, Rorsman P, Buschard K \& Gromada J 1997 Glucagon-like peptide I and glucose-dependent insulinotropic polypeptide stimulate $\mathrm{Ca}^{2+}$-induced secretion in rat alpha-cells by a protein kinase A-mediated mechanism. Diabetes 46 792-800.

Dinneen S, Alzaid A, Turk D \& Rizza R 1995 Failure of glucagon suppression contributes to postprandial hyperglycaemia in IDDM. Diabetologia 38 337-343.

Dumonteil E, Magnan C, Ritz-Laser B, Meda P, Dussoix P, Gilbert M, Ktorza A \& Philippe J 1998 Insulin, but not glucose lowering corrects the hyperglucagonemia and increased proglucagon messenger ribonucleic acid levels observed in insulinopenic diabetes. Endocrinology 139 4540-4546.

Dumonteil E, Ritz-Laser B, Magnan C, Grigorescu I, Ktorza A \& Philippe J 1999 Chronic exposure to high glucose concentrations increases proglucagon messenger ribonucleic acid levels and glucagon release from InR1G9 cells. Endocrinology $1404644-4650$.

Dumonteil E, Magnan C, Ritz-Laser B, Ktorza A, Meda P \& Philippe J 2000 Glucose regulates proinsulin and prosomatostatin but not proglucagon messenger ribonucleic acid levels in rat pancreatic islets. Endocrinology 141 $174-180$. 
Dunning BE \& Gerich JE 2007 The role of alpha-cell dysregulation in fasting and postprandial hyperglycemia in type 2 diabetes and therapeutic implications. Endocrine Reviews 28 253-283.

Dunning BE, Foley JE \& Ahrén B 2005 Alpha cell function in health and disease: influence of glucagon-like peptide-1. Diabetologia 48 1700-1713.

Eledrisi MS, Alshanti MS, Shah MF, Brolosy B \& Jaha N 2006 Overview of the diagnosis and management of diabetic ketoacidosis. American Journal of the Medical Sciences 331 243-251.

Fehmann HC, Strowski M \& Goke B 1995 Functional characterization of somatostatin receptors expressed on hamster glucagonoma cells. American Journal of Physiology. Endocrinology and Metabolism 268 E40-E47.

Franklin I, Gromada J, Gjinovci A, Theander S \& Wollheim CB $2005 \beta$-cell secretory products activate $\alpha$-cell ATP-dependent potassium channels to inhibit glucagon release. Diabetes 54 1808-1815.

Furuta M, Zhou A, Webb G, Carroll R, Ravazzola M, Orci L \& Steiner DF 2001 Severe defect in proglucagon processing in islet A-cells of prohormone convertase 2 null mice. Journal of Biological Chemistry 276 27197-27202.

Gastaldelli A, Baldi S, Pettiti M, Toschi E, Camastra S, Natali A, Landau BR \& Ferrannini E 2000 Influence of obesity and type 2 diabetes on gluconeogenesis and glucose output in humans: a quantitative study. Diabetes 49 1367-1373.

Gedulin BR, Jodka CM, Herrmann K \& Young AA 2006 Role of endogenous amylin in glucagon secretion and gastric emptying in rats demonstrated with the selective antagonist, AC187. Regulatory Peptides 137 $121-127$.

Gelling RW, Du XQ, Dichmann DS, Romer J, Huang H, Cui L, Obici S, Tang B, Holst JJ, Fledelius C et al. 2003 Lower blood glucose, hyperglucagonemia, and pancreatic alpha cell hyperplasia in glucagon receptor knockout mice. PNAS 100 1438-1443.

Gopel S, Kanno T, Barg S, Galvanovskis J \& Rorsman P 1999 Voltage-gated and resting membrane currents recorded from $\beta$-cells in intact mouse pancreatic islets. Journal of Physiology 521 717-728.

Gopel SO, Kanno T, Barg S \& Rorsman P 2000 Patch-clamp characterisation of somatostatin-secreting delta-cells in intact mouse pancreatic islets. Journal of Physiology 528 497-507.

Gorus FK, Malaisse WJ \& Pipeleers DG 1984 Differences in glucose handling by pancreatic A- and B-cells. Journal of Biological Chemistry 259 1196-1200.

Grapengiesser E, Salehi A, Qader SS \& Hellman B 2006 Glucose induces glucagon release pulses antisynchronous with insulin and sensitive to purinoceptor inhibition. Endocrinology 147 3472-3477.

Gravholt CH, Moller N, Jensen MD, Christiansen JS \& Schmitz O 2001 Physiological levels of glucagon do not influence lipolysis in abdominal adipose tissue as assessed by microdialysis. Journal of Clinical Endocrinology and Metabolism 86 2085-2089.

Gremlich S, Bonny C, Waeber G \& Thorens B 1997 Fatty acids decrease IDX-1 expression in rat pancreatic islets and reduce GLUT2, glucokinase, insulin, and somatostatin levels. Journal of Biological Chemistry 272 30261-30269.

Gromada J, Bokvist K, Ding WG, Barg S, Buschard K, Renstrom E \& Rorsman P 1997 Adrenaline stimulates glucagon secretion in pancreatic A-cells by increasing the $\mathrm{Ca}^{2+}$ current and the number of granules close to the L-type $\mathrm{Ca}^{2+}$ channels. Journal of General Physiology 110 217-228.

Gromada J, Hoy M, Buschard K, Salehi A \& Rorsman P 2001 Somatostatin inhibits exocytosis in rat pancreatic $\alpha$-cells by Gi2-dependent activation of calcineurin and depriming of secretory granules. Journal of Physiology $\mathbf{5 3 5}$ 519-532.

Gromada J, Ma X, Hoy M, Bokvist K, Salehi A, Berggren PO \& Rorsman P 2004 ATP-sensitive $\mathrm{K}^{+}$channel-dependent regulation of glucagon release and electrical activity by glucose in wild-type and SUR $1-/-$ mouse alpha-cells. Diabetes 53 (Suppl 3) S181-S189.

Gromada J, Franklin I \& Wollheim CB 2007 Alpha-cells of the endocrine pancreas: 35 years of research but the enigma remains. Endocrine Reviews $\mathbf{2 8}$ 84-116.

Guenifi A, Ahren B \& Abdel-Halim SM 2001 Differential effects of glucagonlike peptide-1 (7-36)amide versus cholecystokinin on arginine-induced islet hormone release in vivo and in vitro. Pancreas 22 58-64.
Gyulkhandanyan AV, Lu H, Lee SC, Bhattacharjee A, Wijesekara N, Fox JE, MacDonald PE, Chimienti F, Dai FF \& Wheeler MB 2008 Investigation of transport mechanisms and regulation of intracellular $\mathrm{Zn}^{2+}$ in pancreatic $\alpha$-cells. Journal of Biological Chemistry 283 10184-10197.

Hayashi M, Otsuka M, Morimoto R, Muroyama A, Uehara S, Yamamoto A \& Moriyama Y 2003a Vesicular inhibitory amino acid transporter is present in glucagon-containing secretory granules in alphaTC6 cells, mouse clonal alpha-cells, and alpha-cells of islets of Langerhans. Diabetes 52 2066-2074.

Hayashi M, Yamada H, Uehara S, Morimoto R, Muroyama A, Yatsushiro S, Takeda J, Yamamoto A \& Moriyama Y 2003b Secretory granule-mediated co-secretion of L-glutamate and glucagon triggers glutamatergic signal transmission in islets of Langerhans. Journal of Biological Chemistry 278 1966-1974.

Heimberg H, De Vos A, Pipeleers D, Thorens B \& Schuit F 1995 Differences in glucose transporter gene expression between rat pancreatic alpha- and beta-cells are correlated to differences in glucose transport but not in glucose utilization. Journal of Biological Chemistry 270 8971-8975.

Heimberg H, De Vos A, Moens K, Quartier E, Bouwens L, Pipeleers D, Van Schaftingen E, Madsen O \& Schuit F 1996 The glucose sensor protein glucokinase is expressed in glucagon-producing alpha $\alpha$-cells. PNAS $\mathbf{9 3}$ 7036-7041.

Herzig S, Long F, Jhala US, Hedrick S, Quinn R, Bauer A, Rudolph D, Schutz G, Yoon C, Puigserver P et al. 2001 CREB regulates hepatic gluconeogenesis through the coactivator PGC-1. Nature 413 179-183.

Hjorth SA, Adelhorst K, Pedersen BB, Kirk O \& Schwartz TW 1994 Glucagon and glucagon-like peptide 1: selective receptor recognition via distinct peptide epitopes. Journal of Biological Chemistry 269 30121-30124.

Hong J, Abudula R, Chen J, Jeppesen PB, Dyrskog SEU, Xiao J, Colombo M \& Hermansen K 2005 The short-term effect of fatty acids on glucagon secretion is influenced by their chain length, spatial configuration, and degree of unsaturation: studies in vitro. Metabolism 54 1329-1336.

Hong J, Jeppesen PB, Nordentoft I \& Hermansen K 2007 Fatty acid-induced effect on glucagon secretion is mediated via fatty acid oxidation. Diabetes/Metabolism Research and Reviews 23 202-210.

Hoy M, Bokvist K, Xiao-Gang W, Hansen J, Juhl K, Berggren PO, Buschard K \& Gromada J 2001 Phentolamine inhibits exocytosis of glucagon by Gi2 protein-dependent activation of calcineurin in rat pancreatic alpha-cells. Journal of Biological Chemistry 276 924-930.

Hunyady B, Hipkin RW, Schonbrunn A \& Mezey E 1997 Immunohistochemical localization of somatostatin receptor SST2A in the rat pancreas. Endocrinology 138 2632-2635.

Inagaki N, Kuromi H, Gonoi T, Okamoto Y, Ishida H, Seino Y, Kaneko T, Iwanaga T \& Seino S 1995 Expression and role of ionotropic glutamate receptors in pancreatic islet cells. FASEB Journal 9 686-691.

Ishihara H, Maechler P, Gjinovci A, Herrera PL \& Wollheim CB 2003 Islet beta-cell secretion determines glucagon release from neighbouring alphacells. Nature Cell Biology 5 330-335.

Juhl CB, Hollingdal M, Sturis J, Jakobsen G, Agerso H, Veldhuis J, Porksen N \& Schmitz O 2002 Bedtime administration of NN2211, a long-acting GLP-1 derivative, substantially reduces fasting and postprandial glycemia in type 2 diabetes. Diabetes 51 424-429.

Kaneko K, Shirotani T, Araki E, Matsumoto K, Taguchi T, Motoshima H, Yoshizato K, Kishikawa H \& Shichiri M 1999 Insulin inhibits glucagon secretion by the activation of PI3-kinase in In-R1-G9 cells. Diabetes Research and Clinical Practice 44 83-92.

Kendall DM, Poitout V, Olson LK, Sorenson RL \& Robertson RP 1995 Somatostatin coordinately regulates glucagon gene expression and exocytosis in HIT-T15 cells. Journal of Clinical Investigation 96 2496-2502.

Kuhara T, Ikeda S, Ohneda A \& Sasaki Y 1991 Effects of intravenous infusion of 17 amino acids on the secretion of GH, glucagon, and insulin in sheep. American Journal of Physiology. Endocrinology and Metabolism 260 E21-E26.

Kumar U, Sasi R, Suresh S, Patel A, Thangaraju M, Metrakos P, Patel SC \& Patel YC 1999 Subtype-selective expression of the five somatostatin receptors (hSSTR1-5) in human pancreatic islet cells: a quantitative double-label immunohistochemical analysis. Diabetes 48 77-85. 
Kurland IJ \& Pilkis SJ 1995 Covalent control of 6-phosphofructo-2kinase/fructose-2,6-bisphosphatase: insights into autoregulation of a bifunctional enzyme. Protein Science 4 1023-1037.

Landstedt-Hallin L, Adamson U \& Lins PE 1999 Oral glibenclamide suppresses glucagon secretion during insulin-induced hypoglycemia in patients with type 2 diabetes. Journal of Clinical Endocrinology and Metabolism 84 3140-3145.

Larsson H \& Ahren B 2000 Islet dysfunction in insulin resistance involves impaired insulin secretion and increased glucagon secretion in postmenopausal women with impaired glucose tolerance. Diabetes Care 23 650-657.

Leclercq-Meyer V, Marchand J, Woussen-Colle MC, Giroix MH \& Malaisse WJ 1985 Multiple effects of leucine on glucagon, insulin, and somatostatin secretion from the perfused rat pancreas. Endocrinology 116 1168-1174.

Leung YM, Ahmed I, Sheu L, Tsushima RG, Diamant NE, Hara M \& Gaisano HY 2005 Electrophysiological characterization of pancreatic islet cells in the mouse insulin promoter-green fluorescent protein mouse. Endocrinology 146 4766-4775.

Leung YM, Ahmed I, Sheu L, Gao X, Hara M, Tsushima RG, Diamant NE \& Gaisano HY 2006 Insulin regulates islet $\boldsymbol{\alpha}$-cell function by reducing KATP channel sensitivity to adenosine $5^{\prime}$-triphosphate inhibition. Endocrinology $1472155-2162$.

Li Y, Cao X, Li LX, Brubaker PL, Edlund H \& Drucker DJ 2005 Beta-cell $\mathrm{Pdx} 1$ expression is essential for the glucoregulatory, proliferative, and cytoprotective actions of glucagon-like peptide-1. Diabetes $\mathbf{5 4} 482-491$.

Li XC, Liao TD \& Zhuo JL 2008 Long-term hyperglucagonaemia induces early metabolic and renal phenotypes of Type 2 diabetes in mice. Clinical Science 114 591-601.

Liang Y, Osborne MC, Monia BP, Bhanot S, Gaarde WA, Reed C, She P, Jetton TL \& Demarest KT 2004 Reduction in glucagon receptor expression by an antisense oligonucleotide ameliorates diabetic syndrome in $\mathrm{db} / \mathrm{db}$ mice. Diabetes 53 410-417.

Liu YJ, Vieira E \& Gylfe E 2004 A store-operated mechanism determines the activity of the electrically excitable glucagon-secreting pancreatic alphacell. Cell Calcium 35 357-365.

Loubatieres AL, Loubatieres-Mariani MM, Alric R \& Ribes G 1974 Tolbutamide and glucagon secretion. Diabetologia 10 271-276.

Ma X, Zhang Y, Gromada J, Sewing S, Berggren PO, Buschard K, Salehi A, Vikman J, Rorsman P \& Eliasson L 2005 Glucagon stimulates exocytosis in mouse and rat pancreatic alpha-cells by binding to glucagon receptors. Molecular Endocrinology 19 198-212.

MacDonald PE, De Marinis YZ, Ramracheya R, Salehi A, Ma X, Johnson PR, Cox R, Eliasson L \& Rorsman P 2007 A K ATP channel-dependent pathway within alpha cells regulates glucagon release from both rodent and human islets of Langerhans. PLoS Biology 5 e143.

Manning Fox JE, Gyulkhandanyan AV, Satin LS \& Wheeler MB 2006 Oscillatory membrane potential response to glucose in islet beta-cells: a comparison of islet-cell electrical activity in mouse and rat. Endocrinology $1474655-4663$.

Mayo KE, Miller LJ, Bataille D, Dalle S, Goke B, Thorens B \& Drucker DJ 2003 International Union of Pharmacology. XXXV. The glucagon receptor family. Pharmacological Reviews 55 167-194.

McGirr R, Ejbick CE, Carter DE, Andrews JD, Nie Y, Friedman TC \& Dhanvantari S 2005 Glucose dependence of the regulated secretory pathway in alphaTC1-6 cells. Endocrinology 146 4514-4523.

Miki T, Liss B, Minami K, Shiuchi T, Saraya A, Kashima Y, Horiuchi M, Ashcroft F, Minokoshi Y, Roeper J et al. 2001 ATP-sensitive $\mathrm{K}^{+}$channels in the hypothalamus are essential for the maintenance of glucose homeostasis. Nature Neuroscience 4 507-512.

Mojsov S, Heinrich G, Wilson IB, Ravazzola M, Orci L \& Habener JF 1986 Preproglucagon gene expression in pancreas and intestine diversifies at the level of post-translational processing. Journal of Biological Chemistry $26 \mathbf{2}$ 11880-11889.

Munoz A, Hu M, Hussain K, Bryan J, Aguilar-Bryan L \& Rajan AS 2005 Regulation of glucagon secretion at low glucose concentrations: evidence for adenosine triphosphate-sensitive potassium channel involvement. Endocrinology 146 5514-5521.
Nadal A, Quesada I \& Soria B 1999 Homologous and heterologous asynchronicity between identified alpha-, beta- and delta-cells within intact islets of Langerhans in the mouse. Journal of Physiology 517 85-93.

Nauck MA, Heimesaat MM, Behle K, Holst JJ, Nauck MS, Ritzel R, Hufner M \& Schmiegel WH 2002 Effects of glucagon-like peptide 1 on counterregulatory hormone responses, cognitive functions, and insulin secretion during hyperinsulinemic, stepped hypoglycemic clamp experiments in healthy volunteers. Journal of Clinical Endocrinology and Metabolism 87 1239-1246.

Olofsson CS, Salehi A, Gopel SO, Holm C \& Rorsman P 2004 Palmitate stimulation of glucagon secretion in mouse pancreatic alpha-cells results from activation of L-type calcium channels and elevation of cytoplasmic calcium. Diabetes 53 2836-2843.

Olsen HL, Theander S, Bokvist K, Buschard K, Wollheim CB \& Gromada J 2005 Glucose stimulates glucagon release in single rat alpha-cells by mechanisms that mirror the stimulus-secretion coupling in beta-cells. Endocrinology 146 4861-4870.

Ostenson CG, Nylen A, Grill V, Gutniak M \& Efendic S 1986 Sulfonylureainduced inhibition of glucagon secretion from the perfused rat pancreas: evidence for a direct, non-paracrine effect. Diabetologia 29 861-867.

Paty BW, Ryan EA, Shapiro AM, Lakey JR \& Robertson RP 2002 Intrahepatic islet transplantation in type 1 diabetic patients does not restore hypoglycemic hormonal counterregulation or symptom recognition after insulin independence. Diabetes 51 3428-3434.

Paul GL, Waegner A, Gaskins HR \& Shay NF 1998 Histidine availability alters glucagon gene expression in murine alphaTC6 cells. Journal of Nutrition 128 973-976.

Pereverzev A, Salehi A, Mikhna M, Renstrom E, Hescheler J, Weiergraber M, Smyth N \& Schneider T 2005 The ablation of the Ca(v)2.3/E-type voltage-gated $\mathrm{Ca}^{2+}$ channel causes a mild phenotype despite an altered glucose induced glucagon response in isolated islets of Langerhans. European Journal of Pharmacology 511 65-72.

Petersen KF \& Sullivan JT 2001 Effects of a novel glucagon receptor antagonist (Bay 27-9955) on glucagon-stimulated glucose production in humans. Diabetologia 44 2018-2024.

Philippe J, Morel C \& Cordier-Bussat M 1995 Islet-specific proteins interact with the insulin-response element of the glucagon gene. Journal of Biological Chemistry 270 3039-3045.

Pipeleers DG, Schuit FC, Van Schravendijk CF \& Van de Winkel M 1985 Interplay of nutrients and hormones in the regulation of glucagon release. Endocrinology 117 817-823.

Quesada I, Nadal A \& Soria B 1999 Different effects of tolbutamide and diazoxide in alpha, beta-, and delta-cells within intact islets of Langerhans. Diabetes 48 2390-2397.

Quesada I, Fuentes E, Andreu E, Meda P, Nadal A \& Soria B 2003 On-line analysis of gap junctions reveals more efficient electrical than dye coupling between islet cells. American Journal of Physiology. Endocrinology and Metabolism 284 E980-E987.

Quesada I, Todorova MG \& Soria B 2006a Different metabolic responses in $\alpha-\beta-$, and $\delta$-cells of the islet of Langerhans monitored by redox confocal microscopy. Biophysical Journal 90 2641-2650.

Quesada I, Todorova MG, Alonso-Magdalena P, Beltra M, Carneiro EM, Martin F, Nadal A \& Soria B $2006 b$ Glucose induces opposite intracellular $\mathrm{Ca}^{2+}$ concentration oscillatory patterns in identified $\alpha$ - and $\beta$-cells within intact human islets of Langerhans. Diabetes 55 2463-2469.

Quoix N, Cheng-Xue R, Guiot Y, Herrera PL, Henquin JC \& Gilon P 2007 The GluCre-ROSA26EYFP mouse: a new model for easy identification of living pancreatic alpha-cells. FEBS Letters $\mathbf{5 8 1} 4235-4240$.

Qureshi SA, Rios CM, Xie D, Yang X, Tota LM, Ding VD, Li Z, Bansal A, Miller C, Cohen SM et al. 2004 A novel glucagon receptor antagonist inhibits glucagon-mediated biological effects. Diabetes 53 3267-3273.

Ravier MA \& Rutter GA 2005 Glucose or insulin, but not zinc ions, inhibit glucagon secretion from mouse pancreatic alpha-cells. Diabetes $\mathbf{5 4}$ 1789-1797.

Reaven GM, Chen YD, Golay A, Swislocki AL \& Jaspan JB 1987 Documentation of hyperglucagonemia throughout the day in nonobese and obese patients with noninsulin-dependent diabetes mellitus. Journal of Clinical Endocrinology and Metabolism 64 106-110. 
Rorsman P, Berggren PO, Bokvist K, Ericson H, Mohler H, Ostenson CG \& Smith PA 1989 Glucose-inhibition of glucagon secretion involves activation of GABAA-receptor chloride channels. Nature 341 233-236.

Rosenstock J, Baron MA, Dejager S, Mills D \& Schweizer A 2007 Comparison of vildagliptin and rosiglitazone monotherapy in patients with type 2 diabetes: a 24-week, double-blind, randomized trial. Diabetes Care 30 217-223.

Schuit FC, Derde MP \& Pipeleers DG 1989 Sensitivity of rat pancreatic A and B cells to somatostatin. Diabetologia 32 207-212.

Schuit F, De Vos A, Farfari S, Moens K, Pipeleers D, Brun T \& Prentki M 1997 Metabolic fate of glucose in purified islet cells. Glucose-regulated anaplerosis in beta cells. Journal of Biological Chemistry 272 18572-18579.

Sekine N, Cirulli V, Regazzi R, Brown LJ, Gine E, Tamarit-Rodriguez J, Girotti M, Marie S, MacDonald MJ, Wollheim CB et al. 1994 Low lactate dehydrogenase and high mitochondrial glycerol phosphate dehydrogenase in pancreatic beta-cells. Potential role in nutrient sensing. Journal of Biological Chemistry 269 4895-4902.

Shah P, Basu A, Basu R \& Rizza R 1999 Impact of lack of suppression of glucagon on glucose tolerance in humans. American Journal of Physiology 277 E283-E290.

Shah P, Vella A, Basu A, Basu R, Schwenk WF \& Rizza RA 2000 Lack of suppression of glucagon contributes to postprandial hyperglycemia in subjects with type 2 diabetes mellitus. Journal of Clinical Endocrinology and Metabolism 85 4053-4059.

Shiota C, Rocheleau JV, Shiota M, Piston DW \& Magnuson MA 2005 Impaired glucagon secretory responses in mice lacking the type 1 sulfonylurea receptor. American Journal of Physiology. Endocrinology and Metabolism 289 E570-E577.

Singh V, Brendel MD, Zacharias S, Mergler S, Jahr H, Wiedenmann B, Bretzel RG, Plockinger U \& Strowski MZ 2007 Characterization of somatostatin receptor subtype-specific regulation of insulin and glucagon secretion: an in vitro study on isolated human pancreatic islets. Journal of Clinical Endocrinology and Metabolism 92 673-680.

Slavin BG, Ong JM \& Kern PA 1994 Hormonal regulation of hormonesensitive lipase activity and mRNA levels in isolated rat adipocytes. Journal of Lipid Research 35 1535-1541.

Sloop KW, Cao JX, Siesky AM, Zhang HY, Bodenmiller DM, Cox AL, Jacobs SJ, Moyers JS, Owens RA, Showalter AD et al. 2004 Hepatic and glucagon-like peptide-1-mediated reversal of diabetes by glucagon receptor antisense oligonucleotide inhibitors. Journal of Clinical Investigation 113 $1571-1581$.

Song Z, Levin BE, McArdle JJ, Bakhos N \& Routh VH 2001 Convergence of pre- and postsynaptic influences on glucosensing neurons in the ventromedial hypothalamic nucleus. Diabetes 50 2673-2681.

Sorensen H, Brand CL, Neschen S, Holst JJ, Fosgerau K, Nishimura E \& Shulman GI 2006 Immunoneutralization of endogenous glucagon reduces hepatic glucose output and improves long-term glycemic control in diabetic ob/ob mice. Diabetes 55 2843-2848.

Strowski MZ, Parmar RM, Blake AD \& Schaeffer JM 2000 Somatostatin inhibits insulin and glucagon secretion via two receptor subtypes: an in vitro study of pancreatic islets from somatostatin receptor 2 knockout mice. Endocrinology 141 111-117.

Strowski MZ, Cashen DE, Birzin ET, Yang L, Singh V, Jacks TM, Nowak KW, Rohrer SP, Patchett AA, Smith RG et al. 2006 Antidiabetic activity of a highly potent and selective nonpeptide somatostatin receptor subtype-2 agonist. Endocrinology 147 4664-4673.

Van Tine BA, Azizeh BY, Trivedi D, Phelps JR, Houslay MD, Johnson DG \& Hruby VJ 1996 Low level cyclic adenosine $3^{\prime}, 5^{\prime}$-monophosphate accumulation analysis of [des-His1, des- Phe6, Glu9] glucagon-NH2 identifies glucagon antagonists from weak partial agonists/antagonists. Endocrinology 137 3316-3322.

Tschritter O, Stumvoll M, Machicao F, Holzwarth M, Weisser M, Maerker E, Teigeler A, Haring H \& Fritsche A 2002 The prevalent Glu23Lys polymorphism in the potassium inward rectifier 6.2 (KIR6.2) gene is associated with impaired glucagon suppression in response to hyperglycemia. Diabetes $\mathbf{5 1}$ 2854-2860.
Tudurí E, Filiputti E, Carneiro EM \& Quesada I 2008 Inhibition of $\mathrm{Ca}^{2+}$ signaling and glucagon secretion in mouse pancreatic alpha-cells by extracellular ATP and purinergic receptors. American Journal of Physiology. Endocrinology and Metabolism 294 E952-E960.

Uehara S, Muroyama A, Echigo N, Morimoto R, Otsuka M, Yatsushiro S \& Moriyama Y 2004 Metabotropic glutamate receptor Type 4 is involved in autoinhibitory cascade for glucagon secretion by $\alpha$-cells of islet of Langerhans. Diabetes 53 998-1006.

Unger RH \& Orci L 1975 The essential role of glucagon in the pathogenesis of diabetes mellitus. Lancet 1 14-16.

Vieira E, Salehi A \& Gylfe E 2007 Glucose inhibits glucagon secretion by a direct effect on mouse pancreatic alpha cells. Diabetologia 50 370-379.

Vons C, Pegorier JP, Girard J, Kohl C, Ivanov MA \& Franco D 1991 Regulation of fatty-acid metabolism by pancreatic hormones in cultured human hepatocytes. Hepatology 13 1126-1130.

Vozzi C, Ullrich S, Charollais A, Philippe J, Orci L \& Meda P 1995 Adequate connexin-mediated coupling is required for proper insulin production. Journal of Cell Biology 131 1561-1572.

Wakelam MJO, Murphy GJ, Hruby VJ \& Houslay MD 1986 Activation of two signal-transduction systems in hepatocytes by glucagon. Nature 323 68-71.

Wang F, Adrian TE, Westermark GT, Ding X, Gasslander T \& Permert J 1999 Islet amyloid polypeptide tonally inhibits beta -, alpha -, and delta-cell secretion in isolated rat pancreatic islets. American Journal of Physiology. Endocrinology and Metabolism 276 E19-E24.

Wendt A, Birnir B, Buschard K, Gromada J, Salehi A, Sewing S, Rorsman P \& Braun M 2004 Glucose inhibition of glucagon secretion from rat $\alpha$-cells is mediated by GABA released from neighboring $\beta$-cells. Diabetes 53 1038-1045.

Winzell MS, Brand CL, Wierup N, Sidelmann UG, Sundler F, Nishimura E \& Ahren B 2007 Glucagon receptor antagonism improves islet function in mice with insulin resistance induced by a high-fat diet. Diabetologia $\mathbf{5 0}$ 1453-1462.

Xu E, Kumar M, Zhang Y, Ju W, Obata T, Zhang N, Liu S, Wendt A, Deng S \& Ebina Y 2006 Intra-islet insulin suppresses glucagon release via GABAGABAA receptor system. Cell Metabolism 3 47-58.

Yamato E, Noma Y, Tahara Y, Ikegami H, Yamamoto Y, Cha T, Yoneda H, Ogihara T, Ohboshi C, Hirota M et al. 1990 Suppression of synthesis and release of glucagon by glucagon-like peptide-1 (7-36 amide) without affect on mRNA level in isolated rat islets. Biochemical and Biophysical Research Communications 167 431-437.

Yoon JC, Puigserver P, Chen G, Donovan J, Wu Z, Rhee J, Adelmant G, Stafford J, Kahn CR, Granner DK et al. 2001 Control of hepatic gluconeogenesis through the transcriptional coactivator PGC-1. Nature 413 131-138.

Yoshimoto Y, Fukuyama Y, Horio Y, Inanobe A, Gotoh M \& Kurachi Y 1999 Somatostatin induces hyperpolarization in pancreatic islet [alpha] cells by activating a $\mathrm{G}$ protein-gated $\mathrm{K}^{+}$channel. FEBS Letters 444 265-269.

Young A 2005 Inhibition of glucagon secretion. Advances in Pharmacology 52 151-171.

Zaitsev SV, Efanov AM, Efanova IB, Larsson O, Ostenson CG, Gold G, Berggren PO \& Efendic S 1996 Imidazoline compounds stimulate insulin release by inhibition of K(ATP) channels and interaction with the exocytotic machinery. Diabetes 45 1610-1618.

Zhao C, Wilson MC, Schuit F, Halestrap AP \& Rutter GA 2001 Expression and distribution of lactate/monocarboxylate transporter isoforms in pancreatic islets and the exocrine pancreas. Diabetes $50361-366$.

Zhou H, Zhang T, Harmon JS, Bryan J \& Robertson RP 2007a Zinc, not insulin, regulates the rat alpha-cell response to hypoglycemia in vivo. Diabetes $\mathbf{5 6}$ 1107-1112.

Zhou H, Zhang T, Oseid E, Harmon J, Tonooka N \& Robertson RP $2007 b$ Reversal of defective glucagon responses to hypoglycemia in insulindependent autoimmune diabetic BB rats. Endocrinology 148 2863-2869.

Received in final form 30 July 2008

Accepted 31 July 2008

Made available online as an Accepted Preprint 31 July 2008 